\title{
Spatiotemporal variability and contribution of different aerosol types to the aerosol optical depth over the Eastern Mediterranean
}

Aristeidis K. Georgoulias et al.

Correspondence to: Aristeidis K. Georgoulias (argeor@env.duth.gr)

The copyright of individual parts of the supplement might differ from the CC-BY 3.0 licence. 


\section{Gridding methodology}

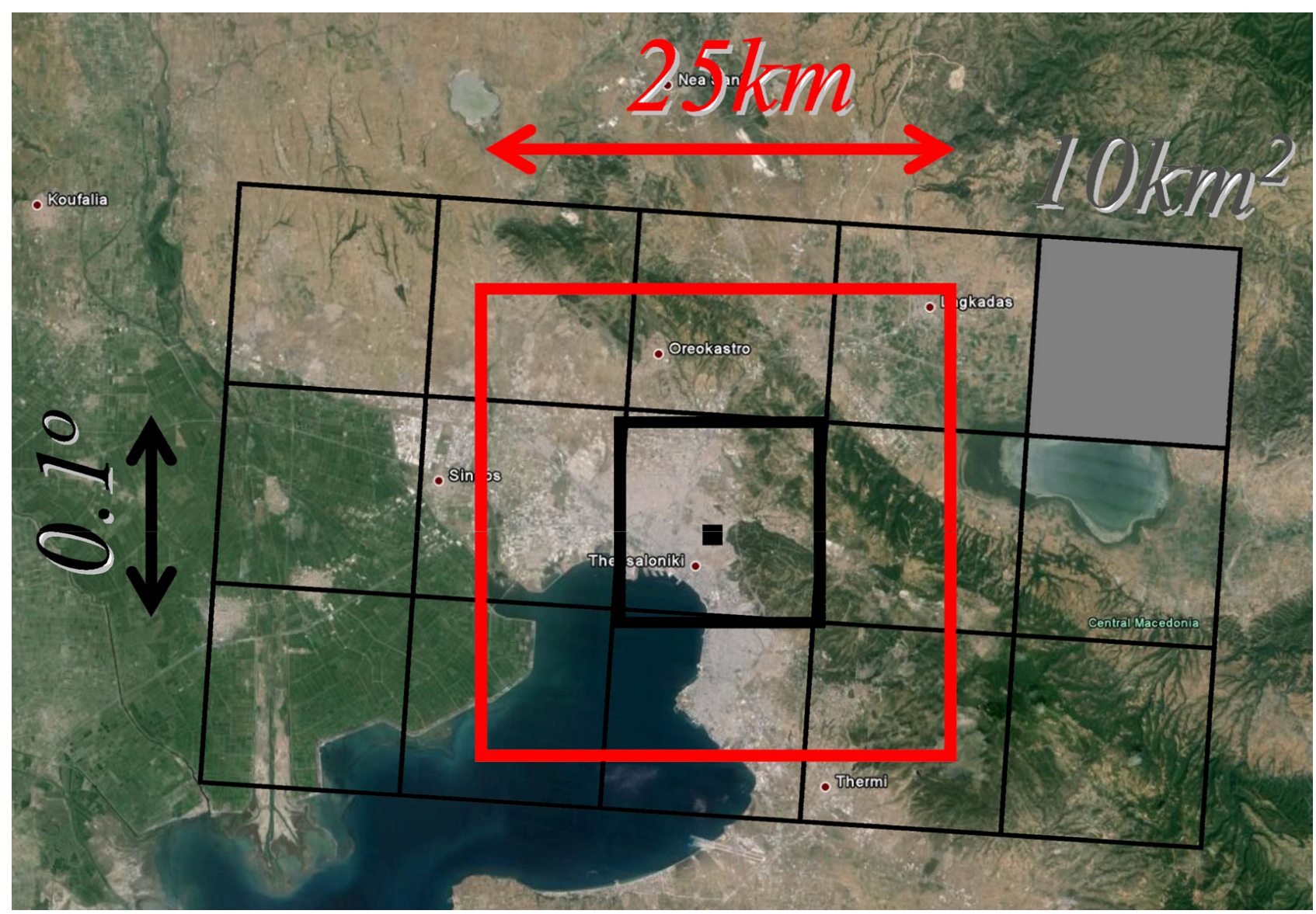

Figure S1. Graphical representation of MODIS level-2 pixels ( $\sim 10 \mathrm{~km}$ resolution at nadir) and a $0.1^{\mathrm{o}} \times 0.1^{\mathrm{o}}$ grid cell (square marked with a black thick line) centered in the city of Thessaloniki, Northern Greece. One can see the $25 \mathrm{~km}$ window used for the gridding procedure (square marked with a red thick line). All the MODIS pixels centered within the $25 \times 25 \mathrm{~km}^{2}$ square window around the grid cell are attributed to it and are used for the calculation of the daily averages. It is obvious that a grid cell of $0.1^{\circ} \times 0.1^{\circ}$ is has nearly the size of the centre of a large Mediterranean city like Thessaloniki ( $\sim 1$ million inhabitants). 
a)

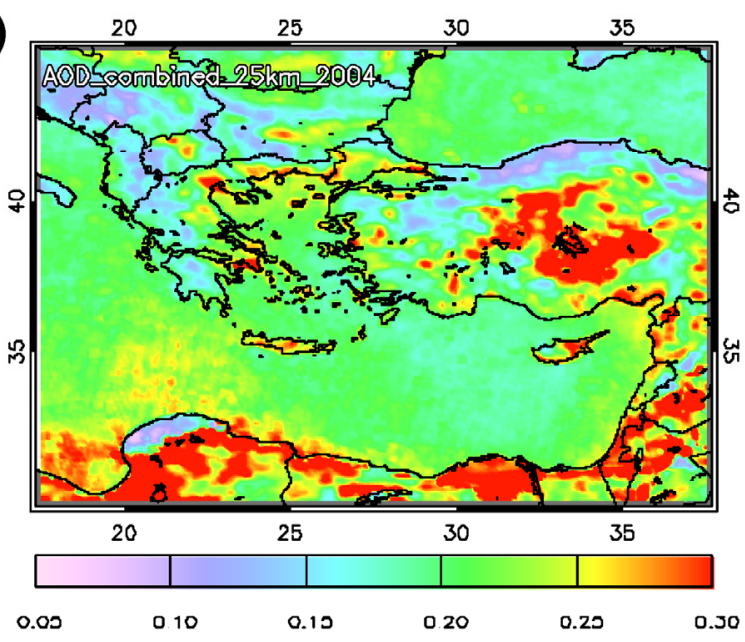

c)

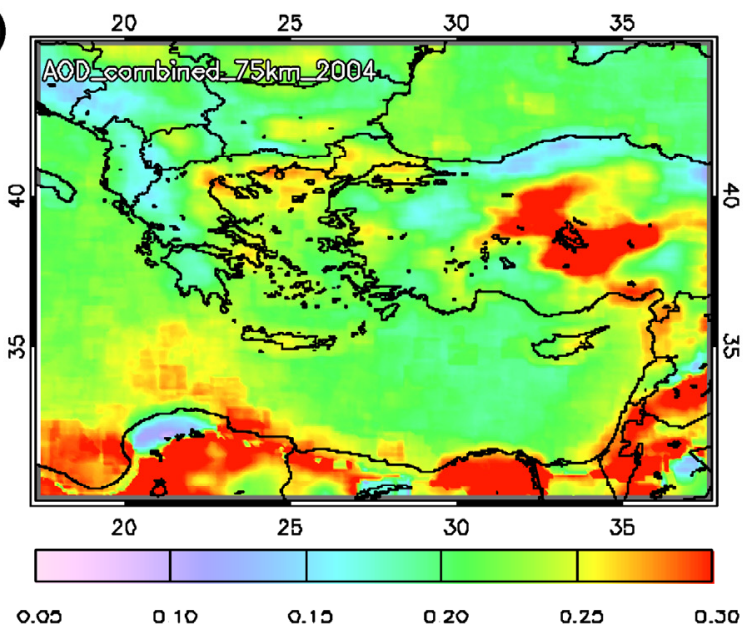

b)

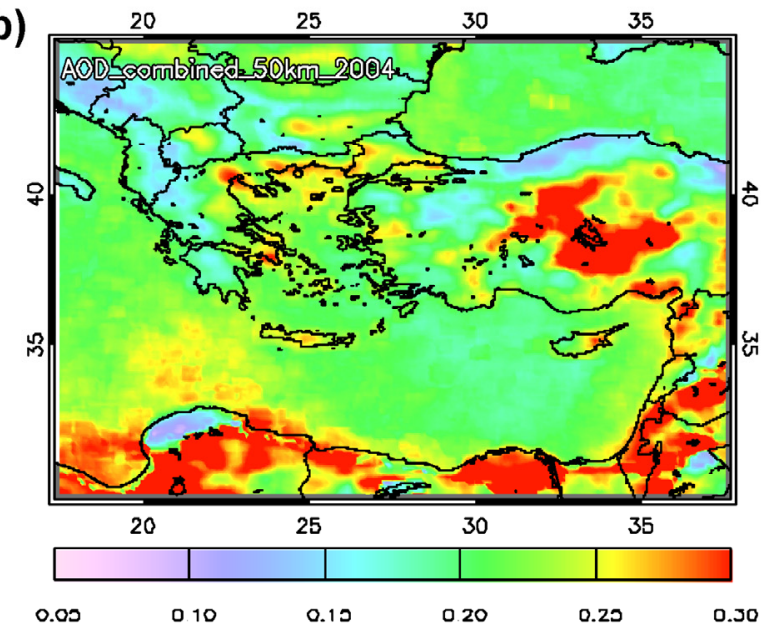

d)

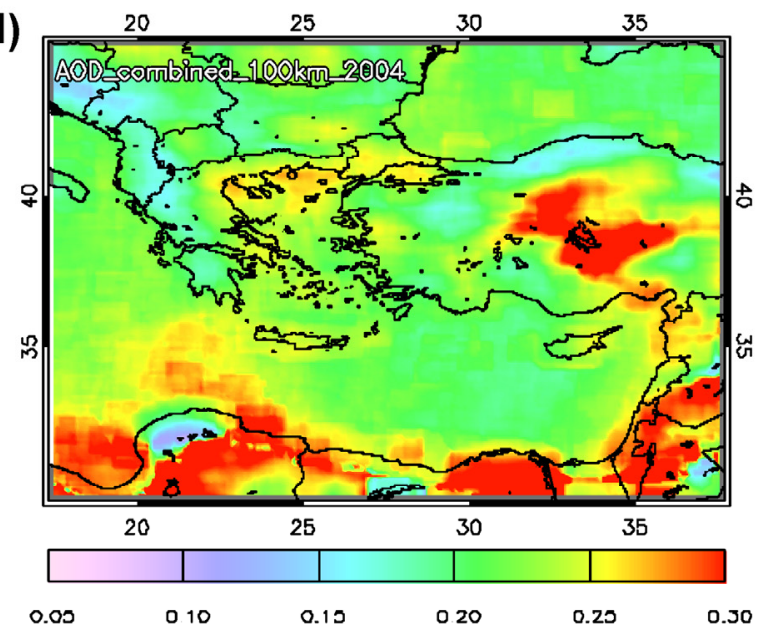

Figure S2. MODIS Terra $0.1^{\circ}$ x $0.1^{\circ}$ resolution $\mathrm{AOD}_{550}$ patterns over the Eastern Mediterranean for the year 2004 as calculated using gridding windows of different sizes: a) $25 \times 25 \mathrm{~km}^{2}$, b) $50 \times 50$ $\mathrm{km}^{2}$, c) $75 \times 75 \mathrm{~km}^{2}$, d) $100 \times 100 \mathrm{~km}^{2}$. It is apparent that the $25 \times 25 \mathrm{~km}^{2}$ gridding window allows for spotting local sources that cannot be seen if a bigger window is used. 


\section{Optimizing the algorithm}

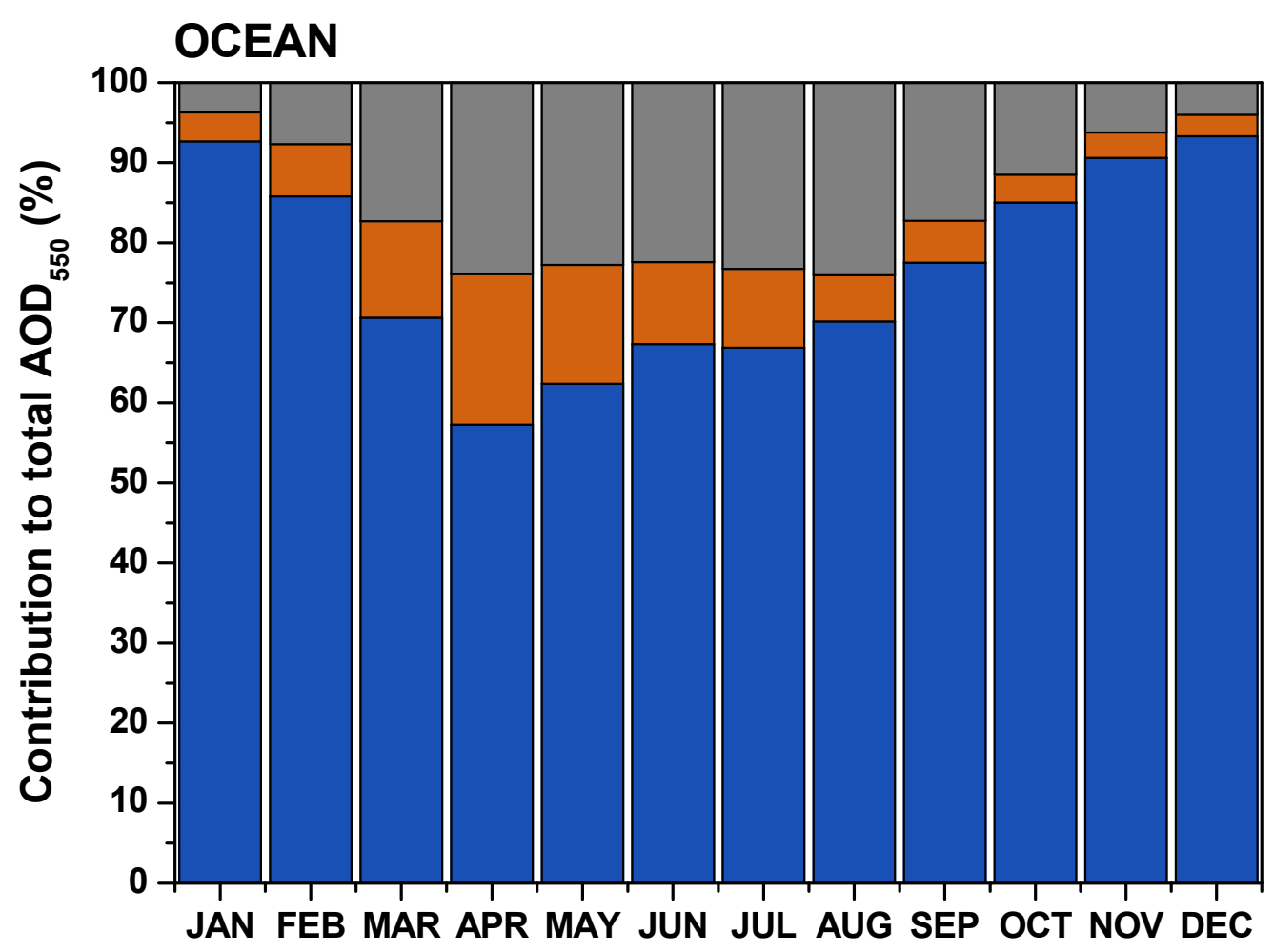

Figure S3. Relative contribution of marine aerosols (blue), dust (orange) and anthropogenic aerosols (grey) on a monthly basis over the Eastern Mediterranean calculated from MODIS Terra data for the period 3/2000-12/2012. The results presented here are from the original Bellouin et al. (2008) algorithm. 
a)

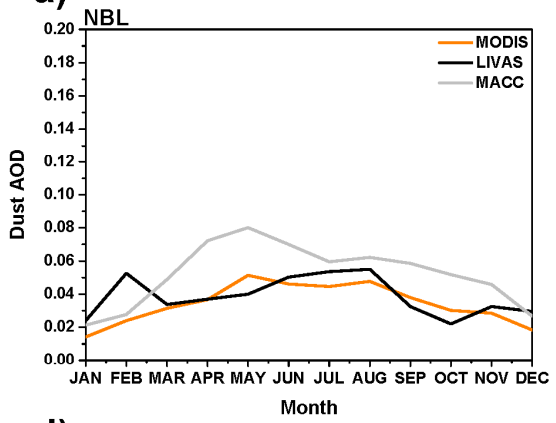

d)

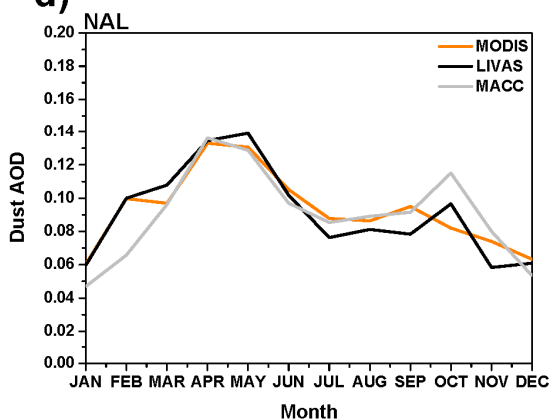

g)

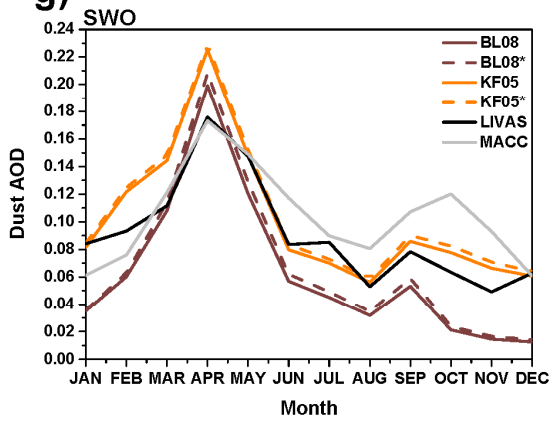

b)

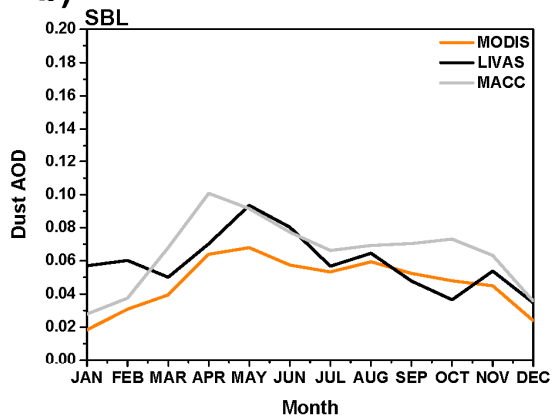

e)

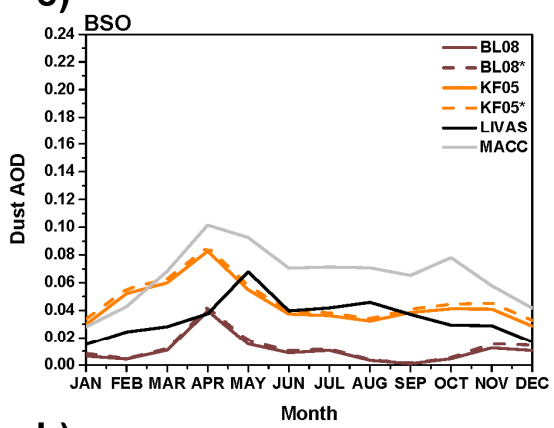

h)

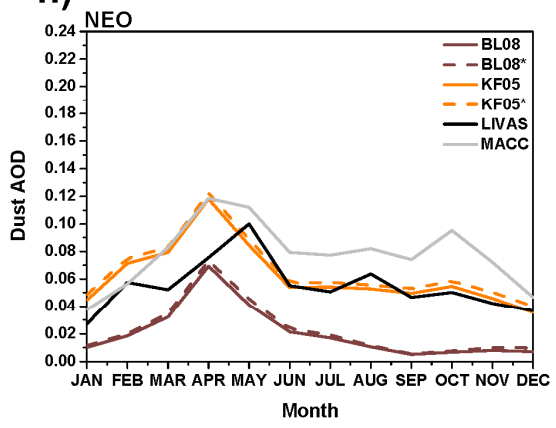

c)

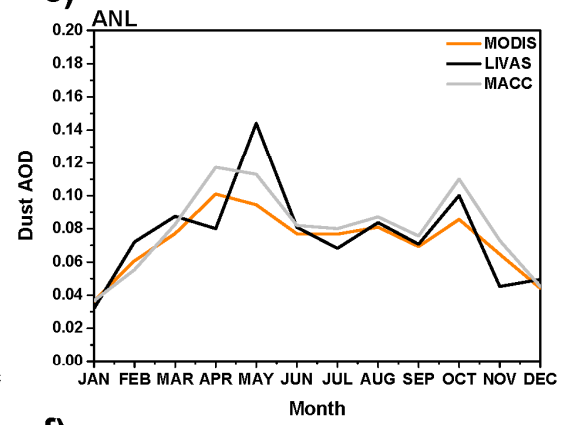

f)

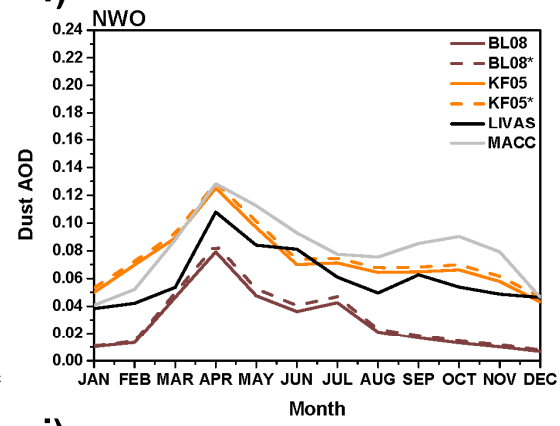

i)

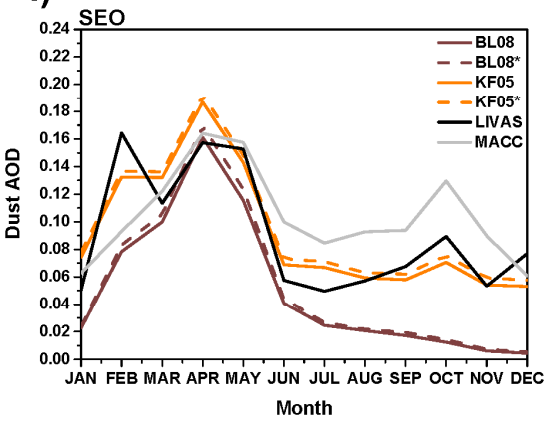

Figure S4. Seasonal variability of dust using Terra MODIS based $\tau_{\mathrm{d}}$ data from the algorithm presented in this work (orange color), MACC reanalysis dust $\mathrm{AOD}_{550}$ data (grey color) and LIVAS CALIOP/CALIPSO dust AOD $_{532}$ data (black color). Brown color is used for MODIS based results when applying the original Bellouin et al. (2008) algorithm. The dashed lines correspond to results assuming stable $\tau_{\mathrm{m}}$ for surface wind speeds less than $5 \mathrm{~m} / \mathrm{s}$ as discussed in the manuscript. 
a)

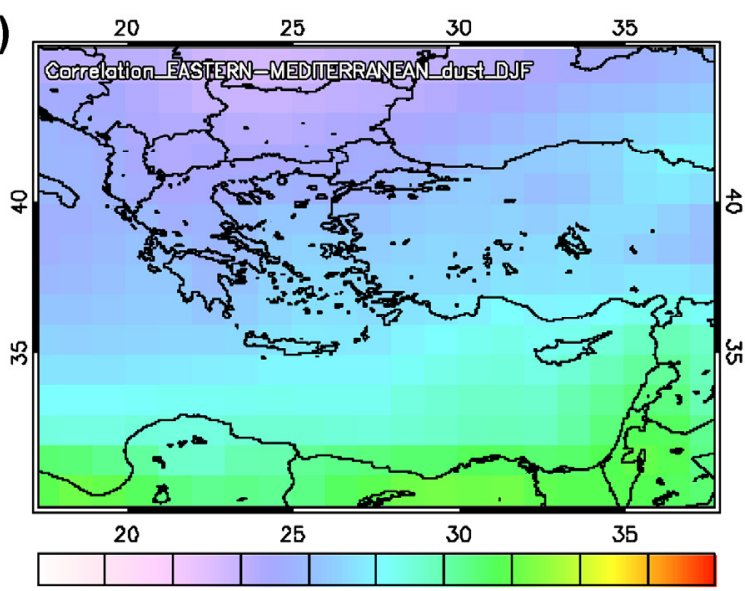

$\begin{array}{lllllllllll}0.00 & 0.10 & 0.20 & 0.30 & 0.40 & 0.50 & 0.60 & 0.70 & 0.80 & 0.90 & 1.00\end{array}$

c)

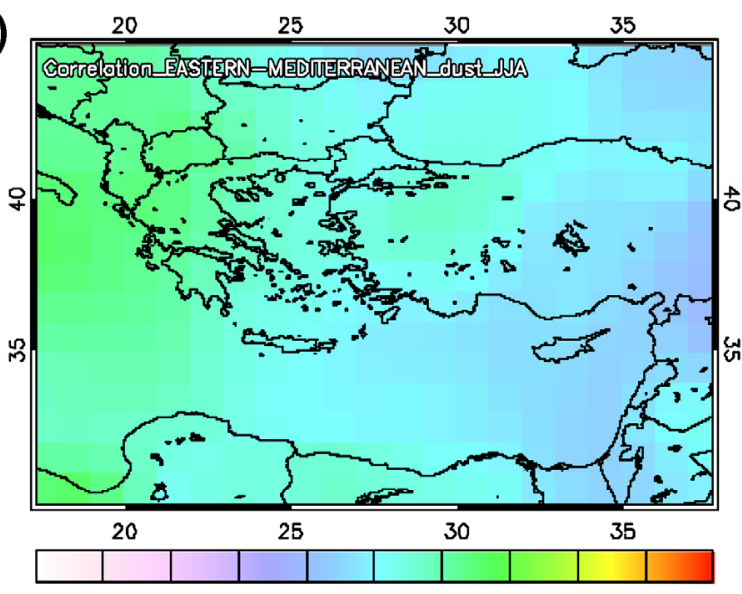

$\begin{array}{lllllllllll}0.00 & 0.10 & 0.20 & 0.30 & 0.40 & 0.50 & 0.60 & 0.70 & 0.80 & 0.90 & 1.00\end{array}$

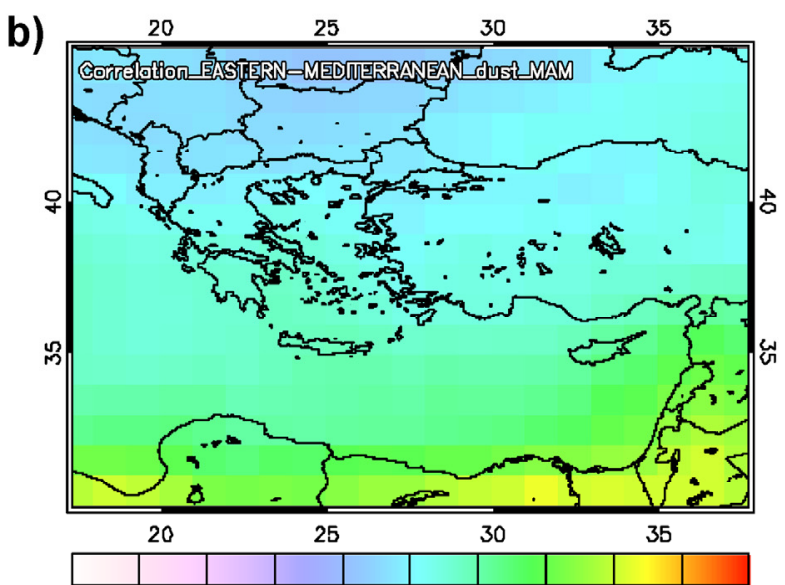

$\begin{array}{lllllllllll}0.00 & 0.10 & 0.20 & 0.30 & 0.40 & 0.50 & 0.60 & 0.70 & 0.80 & 0.90 & 1.00\end{array}$

d)

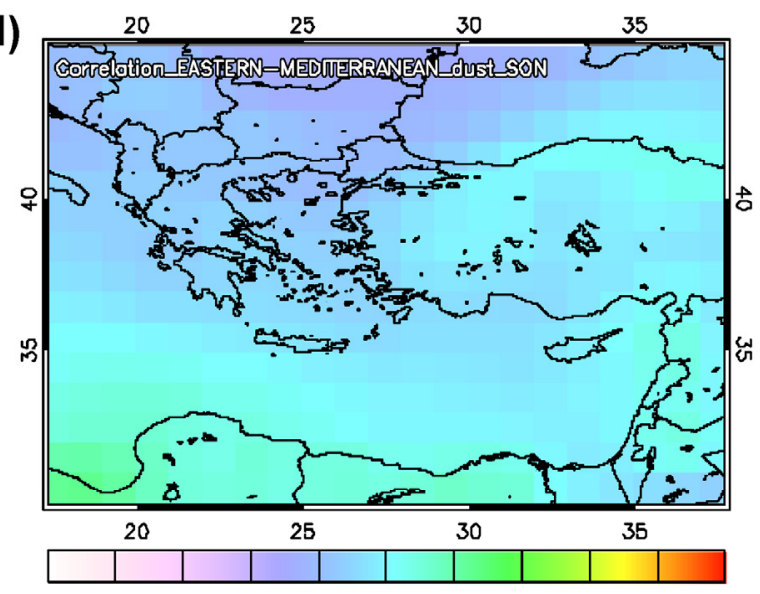

$\begin{array}{lllllllllll}0.00 & 0.10 & 0.20 & 0.30 & 0.40 & 0.50 & 0.80 & 0.70 & 0.80 & 0.90 & 1.00\end{array}$

Figure S5. Slopes of the regression lines between MACC and GOCART $f_{d}$ for the period 20032007. The regression lines are calculated on a grid cell basis for: a) Winter, b) Spring, c) Summer and d) Autumn. 
a)

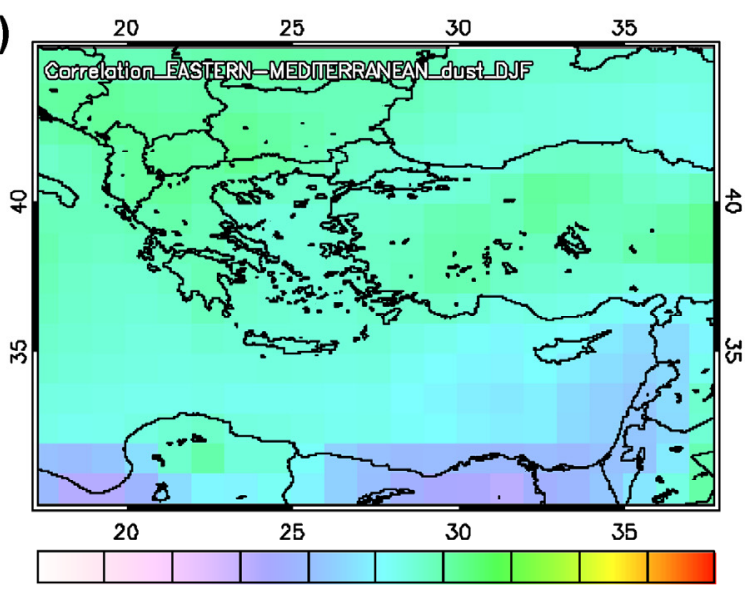

$\begin{array}{lllllll}-0.25-0.20-0.15-0.10-0.05 & 0.00 & 0.05 & 0.10 & 0.15 & 0.20 & 0.25\end{array}$

c)

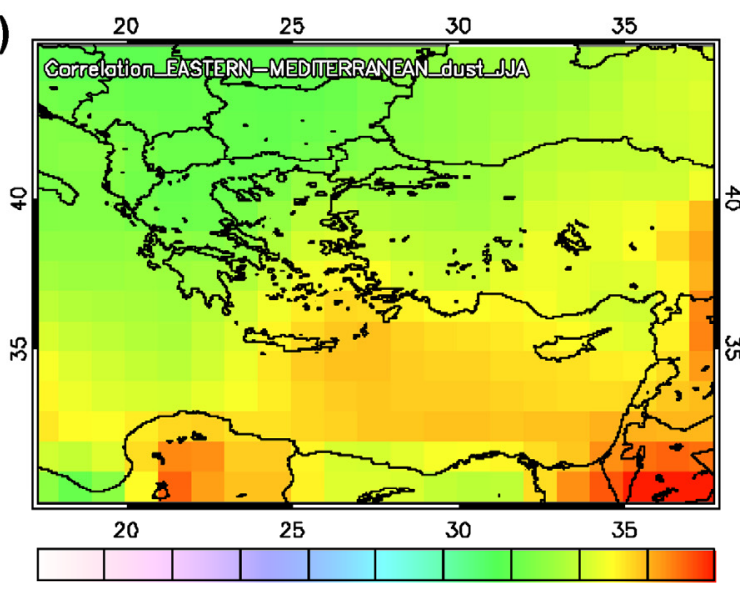

$\begin{array}{lllllll}-0.25-0.20-0.15-0.10-0.05 & 0.00 & 0.05 & 0.10 & 0.15 & 0.20 & 0.25\end{array}$

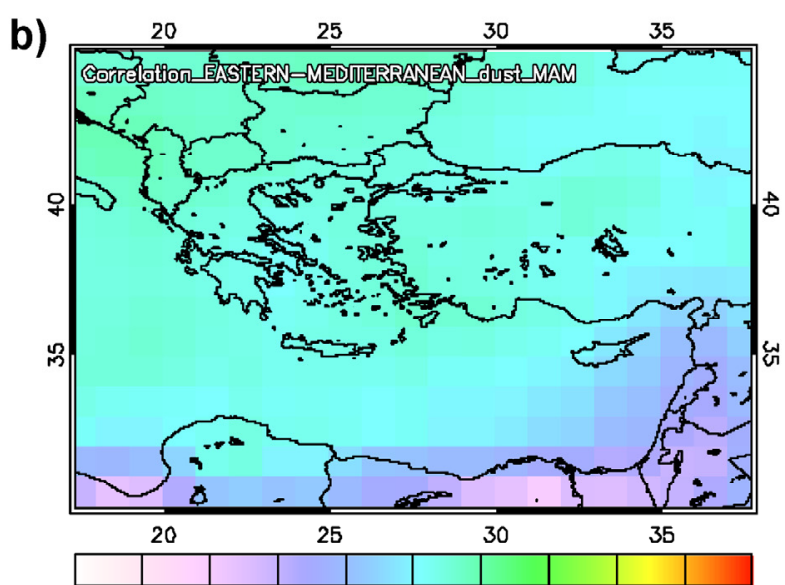

$\begin{array}{lllllll}-0.25-0.20-0.15-0.10-0.05 & 0.00 & 0.05 & 0.10 & 0.15 & 0.20 & 0.25\end{array}$

d)

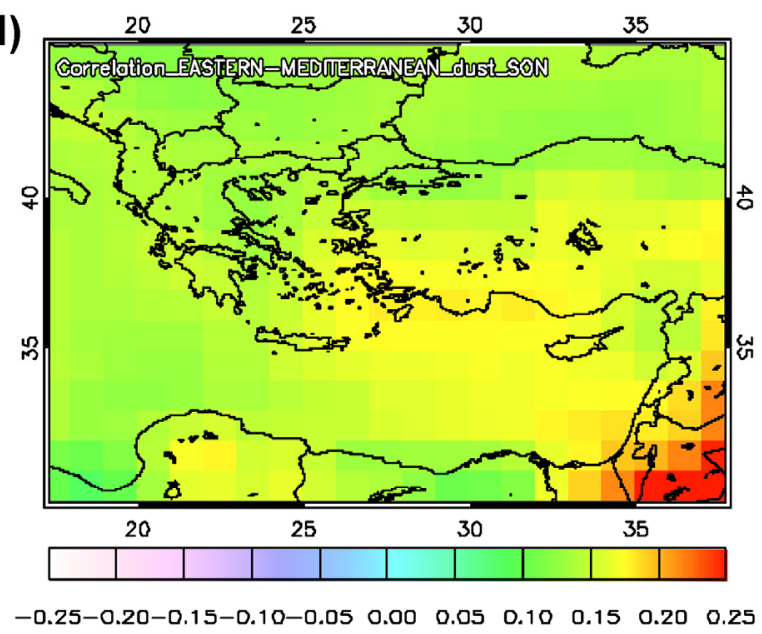

Figure S6. Offset of the regression lines between MACC and GOCART $f_{d}$ for the period 20032007. The regression lines are calculated on a grid cell basis for: a) Winter, b) Spring, c) Summer and d) Autumn. 
a)

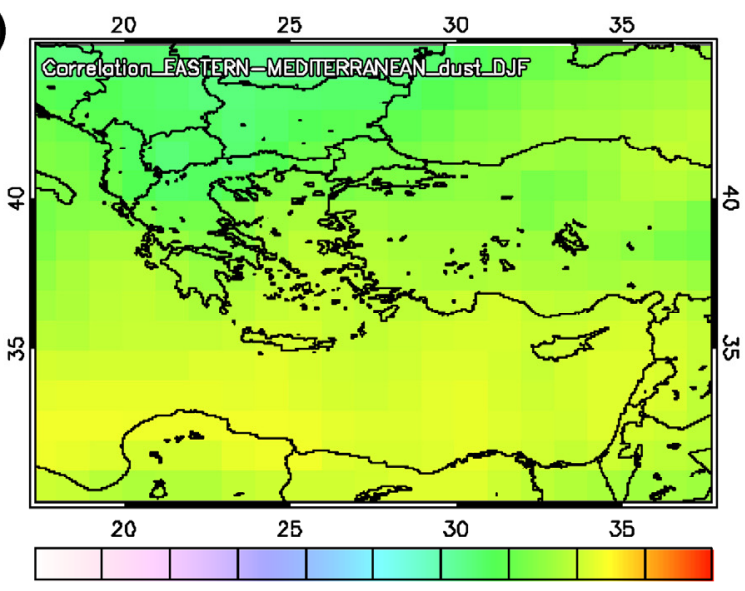

$\begin{array}{lllllllllllll}0.00 & 0.10 & 0.20 & 0.30 & 0.40 & 0.50 & 0.60 & 0.70 & 0.80 & 0.90 & 1.00\end{array}$

c)

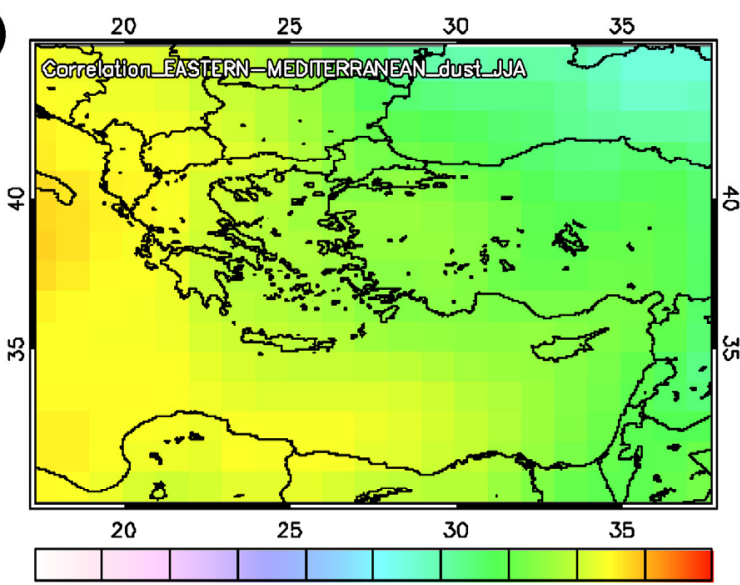

$\begin{array}{lllllllllll}0.00 & 0.10 & 0.20 & 0.30 & 0.40 & 0.50 & 0.60 & 0.70 & 0.80 & 0.90 & 1.00\end{array}$

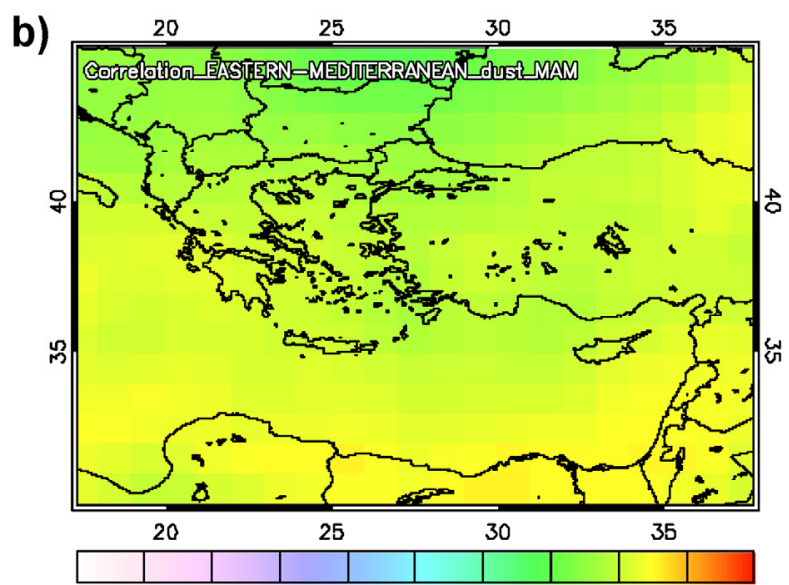

$\begin{array}{llllllllllll}0.00 & 0.10 & 0.20 & 0.30 & 0.40 & 0.50 & 0.80 & 0.70 & 0.80 & 0.90 & 1.00\end{array}$

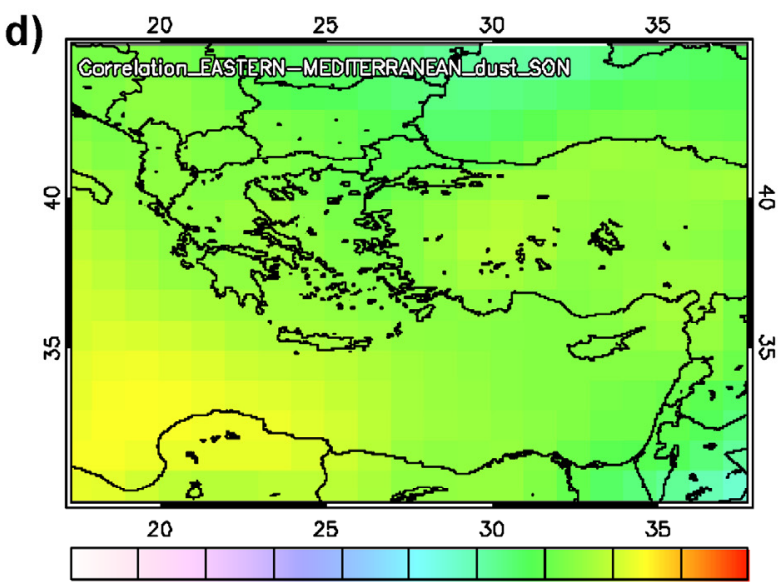

$\begin{array}{llllllllllll}0.00 & 0.10 & 0.20 & 0.30 & 0.40 & 0.50 & 0.80 & 0.70 & 0.80 & 0.90 & 1.00\end{array}$

Figure S7. Correlation coefficients (R) for MACC and GOCART $f_{d}$ for the period 2003-2007. The regression lines are calculated on a grid cell basis for: a) Winter, b) Spring, c) Summer and d) Autumn. 


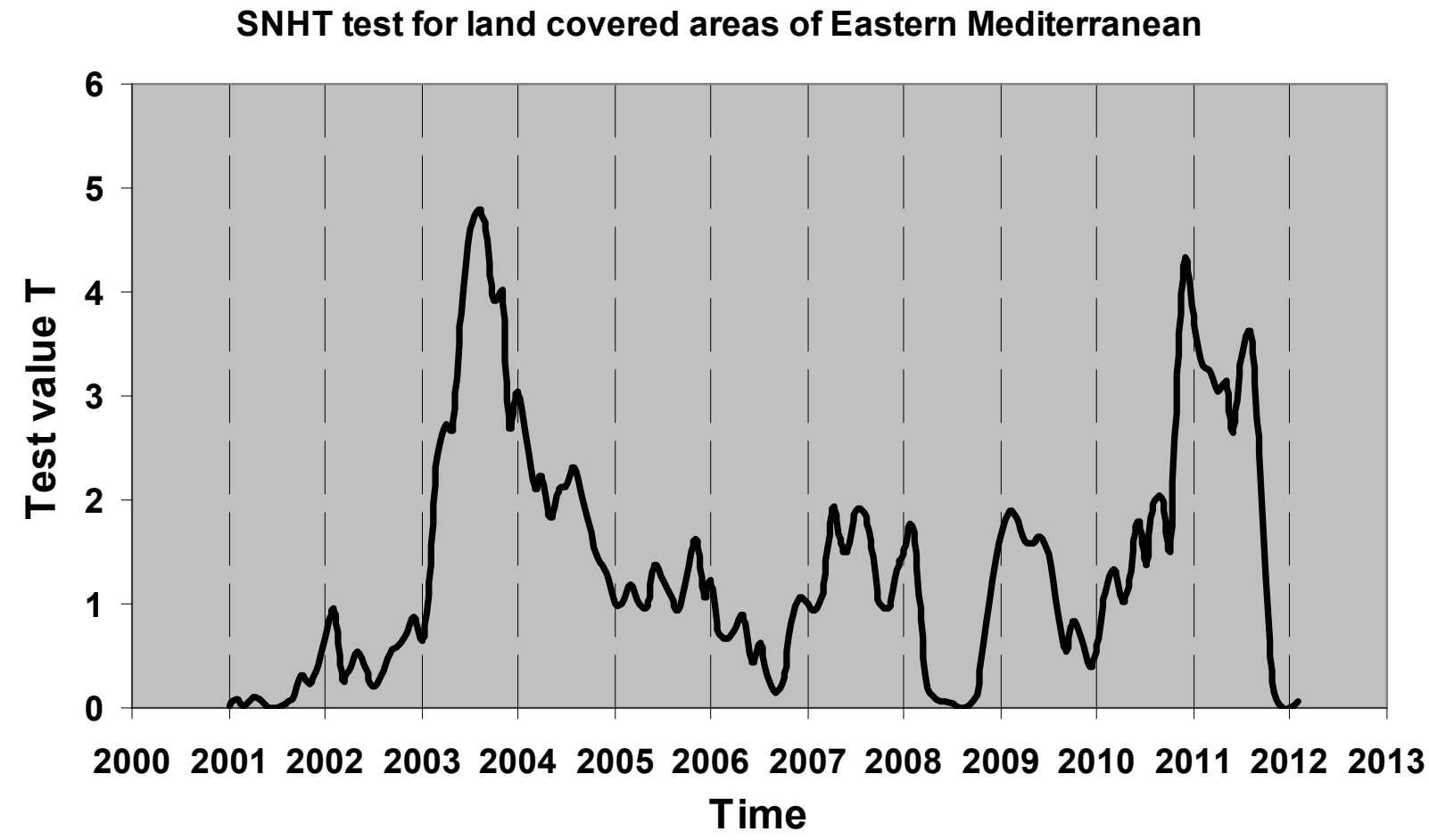

Figure S8. Results of the Standard Normalized Homogeneity Test (SNHT) for deseasonalized $\mathrm{f}_{\mathrm{d}}$ values of the GOCART-MACC merged dataset (2000-2012) for the land areas of the Eastern Mediterranean. The Test value (T) is calculated as in Alexandersson (1986). According to the critical values given in Khaliq and Ouarda (2007) the $\mathrm{f}_{\mathrm{d}}$ timeseries can be considered homogeneous for every confidence level above $90 \%$. 


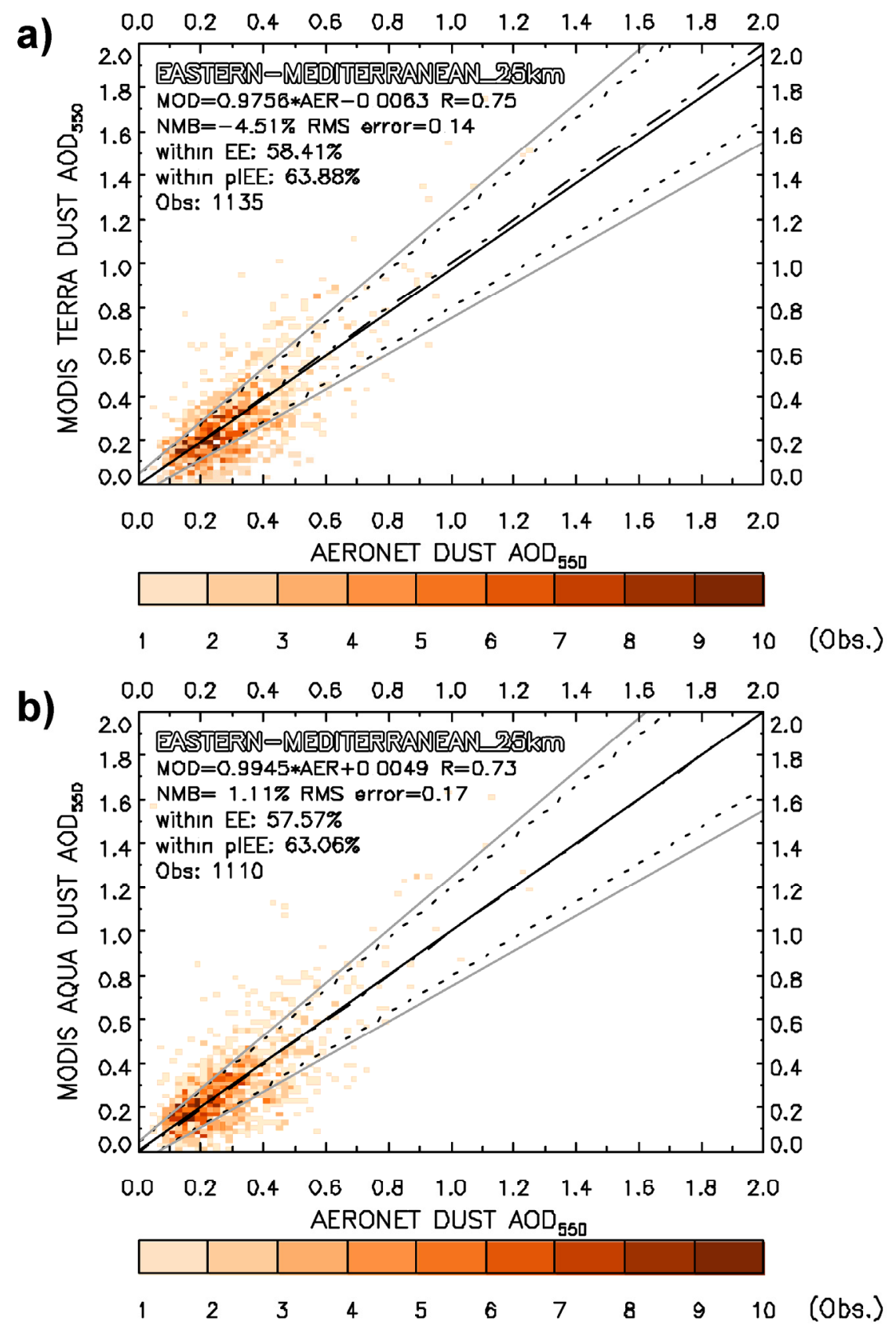

Figure S9. Comparison of spatially (grid cell that encloses the station) and temporally ( $\pm 30 \mathrm{~min}$ from the MODIS overpass time) collocated MODIS dust $\operatorname{AOD}_{550}\left(\tau_{\mathrm{d}}\right)$ and AERONET sunphotometric (quadratically interpolated) dust $\mathrm{AOD}_{550}$ observations for the Eastern Mediterranean stations: (a) for MODIS Terra DT data, (b) for MODIS Aqua DT data. The solid line is the regression line of the MODIS-AERONET observations, the dashed-dotted line is the 1:1 line, the dotted lines represent the EE envelope and the grey lines the plEE envelope. The slope and the intercept of the regression line, the correlation coefficient $\mathrm{R}$, the normalized mean bias (NMB), the root mean square (RMS) error, the percentage of the collocation points that fall within the EE and plEE and the number of all the collocation points. 


\section{Validation results}

Table S1. Results of the comparison of spatially (using a $25 \times 25 \mathrm{~km}^{2}$ window around each station) and temporally ( $\pm 30 \mathrm{~min}$ from the MODIS overpass time) collocated MODIS Terra and Aqua (Italics) DT level-2 Collection 051 and AERONET sunphotometric (quadratically interpolated) $\mathrm{AOD}_{550}$ observations for each Eastern Mediterranean station. The station abbreviation (see Table 1 in the manuscript for full names), the average MODIS and AERONET AOD 550 and the corresponding $\pm 1 \sigma$ values, the mean difference between them, the normalized mean bias (NMB) and the corresponding root mean square (RMS) error, the percentage of the collocation points that fall within the expected error (EE) envelope and the pre-launch expected error (plEE) envelope, the correlation coefficient $\mathrm{R}$, the slope a and the intercept of the regression line and the number of the collocation points are given in the table.

\begin{tabular}{|c|c|c|c|c|c|c|c|c|c|c|c|}
\hline Station & $\begin{array}{l}\text { MODIS Terra } \\
\text { MODIS Aqua }\end{array}$ & AERONET & Mean Diff. & NMB \% & RMS err. & in $\mathrm{EE} \%$ & in plEE \% & $\mathrm{R}$ & $\mathrm{a}$ & $\mathrm{b}$ & Obs \\
\hline \multirow[t]{2}{*}{ ATH } & $0.376 \pm 0.188$ & $0.186 \pm 0.106$ & $0.190 \pm 0.151$ & 101.99 & 0.24 & 25.22 & 26.99 & 0.60 & 1.052 & 0.180 & 226 \\
\hline & $0.398 \pm 0.233$ & $0.190 \pm 0.106$ & $0.208 \pm 0.204$ & 109.38 & 0.29 & 18.32 & 20.94 & 0.49 & 1.071 & 0.194 & 191 \\
\hline \multirow[t]{2}{*}{ BUC } & $0.227 \pm 0.140$ & $0.213 \pm 0.115$ & $0.014 \pm 0.067$ & 6.74 & 0.07 & 79.69 & 83.55 & 0.88 & 1.076 & -0.002 & 389 \\
\hline & $0.257 \pm 0.165$ & $0.225 \pm 0.128$ & $0.032 \pm 0.078$ & 14.17 & 0.08 & 72.89 & 81.33 & 0.89 & 1.14 & 0.000 & 332 \\
\hline \multirow[t]{2}{*}{ CUT } & $0.291 \pm 0.153$ & $0.176 \pm 0.107$ & $0.115 \pm 0.089$ & 65.53 & 0.15 & 36.4 & 41.18 & 0.83 & 1.185 & 0.083 & 272 \\
\hline & $0.346 \pm 0.169$ & $0.184 \pm 0.094$ & $0.163 \pm 0.116$ & 88.56 & 0.20 & 23.89 & 26.55 & 0.75 & 1.362 & 0.096 & 226 \\
\hline \multirow[t]{2}{*}{ EFO } & $0.148 \pm 0.117$ & $0.169 \pm 0.087$ & $-0.021 \pm 0.073$ & -12.43 & 0.08 & 67.49 & 72.02 & 0.78 & 1.046 & -0.029 & 243 \\
\hline & $0.199 \pm 0.144$ & $0.173 \pm 0.084$ & $0.026 \pm 0.091$ & 14.75 & 0.09 & 58.12 & 64.96 & 0.81 & 1.382 & -0.041 & 234 \\
\hline \multirow[t]{2}{*}{ FOR } & $0.226 \pm 0.127$ & $0.174 \pm 0.097$ & $0.053 \pm 0.077$ & 30.23 & 0.09 & 66.51 & 71.08 & 0.79 & 1.031 & 0.047 & 1072 \\
\hline & $0.251 \pm 0.121$ & $0.176 \pm 0.098$ & $0.075 \pm 0.073$ & 42.77 & 0.10 & 52.88 & 57.82 & 0.80 & 0.987 & 0.077 & 1093 \\
\hline \multirow[t]{2}{*}{ IMS } & $0.221 \pm 0.140$ & $0.219 \pm 0.137$ & $0.002 \pm 0.080$ & 0.92 & 0.08 & 78.25 & 82.63 & 0.83 & 0.852 & 0.035 & 800 \\
\hline & $0.247 \pm 0.160$ & $0.217 \pm 0.123$ & $0.030 \pm 0.086$ & 13.84 & 0.09 & 71.87 & 76.52 & 0.85 & 1.096 & 0.009 & 903 \\
\hline \multirow[t]{2}{*}{ LEC } & $0.133 \pm 0.131$ & $0.195 \pm 0.118$ & $-0.062 \pm 0.095$ & -31.85 & 0.11 & 58.58 & 63.13 & 0.72 & 0.793 & -0.022 & 1207 \\
\hline & $0.143 \pm 0.125$ & $0.186 \pm 0.109$ & $-0.043 \pm 0.075$ & -23.1 & 0.09 & 64.14 & 68.81 & 0.80 & 0.923 & -0.029 & 1135 \\
\hline \multirow[t]{2}{*}{ NES } & $0.33 \pm 0.1970$ & $0.245 \pm 0.161$ & $0.085 \pm 0.081$ & 34.47 & 0.12 & 52.73 & 58.62 & 0.92 & 1.124 & 0.054 & 916 \\
\hline & $0.349 \pm 0.228$ & $0.234 \pm 0.175$ & $0.115 \pm 0.091$ & 49.34 & 0.15 & 33.58 & 37.99 & 0.93 & 1.218 & 0.064 & 795 \\
\hline \multirow[t]{2}{*}{ SEV } & $0.167 \pm 0.120$ & $0.167 \pm 0.092$ & $0.000 \pm 0.070$ & 0.16 & 0.07 & 76.86 & 80.72 & 0.82 & 1.068 & -0.011 & 778 \\
\hline & $0.207 \pm 0.126$ & $0.165 \pm 0.087$ & $0.042 \pm 0.075$ & 25.69 & 0.09 & 71.45 & 75.00 & 0.81 & 1.18 & 0.013 & 732 \\
\hline \multirow[t]{2}{*}{ THE } & $0.227 \pm 0.174$ & $0.223 \pm 0.133$ & $0.004 \pm 0.096$ & 1.94 & 0.10 & 71.51 & 76.36 & 0.84 & 1.099 & -0.018 & 516 \\
\hline & $0.272 \pm 0.175$ & $0.221 \pm 0.126$ & $0.050 \pm 0.101$ & 22.75 & 0.11 & 65.83 & 70.84 & 0.82 & 1.146 & 0.018 & 439 \\
\hline \multirow[t]{2}{*}{ TUB } & $0.327 \pm 0.118$ & $0.184 \pm 0.087$ & $0.144 \pm 0.087$ & 78.2 & 0.17 & 22.6 & 23.97 & 0.68 & 0.926 & 0.157 & 146 \\
\hline & $0.347 \pm 0.134$ & $0.172 \pm 0.099$ & $0.175 \pm 0.096$ & 101.74 & 0.20 & 12.37 & 16.49 & 0.70 & 0.944 & 0.185 & 97 \\
\hline \multirow[t]{2}{*}{ XAN } & $0.202 \pm 0.138$ & $0.231 \pm 0.125$ & $-0.029 \pm 0.088$ & -12.45 & 0.09 & 59.85 & 65.91 & 0.78 & 0.864 & 0.003 & 132 \\
\hline & $0.222 \pm 0.139$ & $0.252 \pm 0.130$ & $-0.030 \pm 0.080$ & -12.05 & 0.09 & 72.64 & 78.3 & 0.83 & 0.882 & -0.001 & 106 \\
\hline
\end{tabular}


Table S2. Results of the comparison of spatially (using a spatial window around each station) and temporally ( \pm 30 min from the MODIS overpass time) collocated MODIS Terra and Aqua (Italics) DT level-2 Collection 051 and AERONET sunphotometric (quadratically interpolated) $\mathrm{AOD}_{550}$ observations for the Eastern Mediterranean stations. The spatial window used for the spatial collocation $\left(25 \times 25 \mathrm{~km}^{2}, 50 \times 50 \mathrm{~km}^{2}, 75 \times 75 \mathrm{~km}^{2}\right.$ and $100 \times 100 \mathrm{~km}^{2}$ window around each station) with the AERONET data, the average MODIS and AERONET AOD 550 and the corresponding $\pm 1 \sigma$ values, the mean difference between them, the normalized mean bias (NMB) and the corresponding root mean square (RMS) error, the percentage of the collocation points that fall within the expected error (EE) envelope and the pre-launch expected error (plEE) envelope, the correlation coefficient $\mathrm{R}$, the slope a and the intercept of the regression line and the number of the collocation points are given in the table.

\begin{tabular}{|c|c|c|c|c|c|c|c|c|c|c|c|}
\hline Window & $\begin{array}{l}\text { MODIS Terra } \\
\text { MODIS Aqua }\end{array}$ & AERONET & Mean Diff. & NMB \% & RMS err. & in $\mathrm{EE} \%$ & in pl EE \% & $\mathrm{R}$ & $\mathrm{a}$ & $\mathrm{b}$ & Obs \\
\hline $25 \mathrm{~km}$ & $0.223 \pm 0.163$ & $0.200 \pm 0.123$ & $0.023 \pm 0.106$ & 11.59 & 0.11 & 63.28 & 67.78 & 0.76 & 1.007 & 0.022 & 6697 \\
\hline $25 \mathrm{~km} \mathrm{~s}$ & $0.219 \pm 0.161$ & $0.196 \pm 0.122$ & $0.022 \pm 0.104$ & 11.43 & 0.11 & 63.60 & 68.15 & 0.77 & 1.012 & 0.020 & 5931 \\
\hline $50 \mathrm{~km}$ & $0.216 \pm 0.154$ & $0.200 \pm 0.127$ & $0.016 \pm 0.090$ & 7.74 & 0.09 & 69.80 & 74.07 & 0.81 & 0.981 & 0.019 & 9340 \\
\hline $50 \mathrm{~km} \mathrm{~s}$ & $0.210 \pm 0.153$ & $0.195 \pm 0.125$ & $0.015 \pm 0.088$ & 7.73 & 0.09 & 70.30 & 74.51 & 0.82 & 1.000 & 0.015 & 7991 \\
\hline $50 \mathrm{~km} \mathrm{sr}$ & $0.204 \pm 0.152$ & $0.194 \pm 0.124$ & $0.010 \pm 0.085$ & 5.10 & 0.09 & 70.17 & 74.64 & 0.83 & 1.016 & 0.007 & 6054 \\
\hline $75 \mathrm{~km}$ & $0.211 \pm 0.147$ & $0.200 \pm 0.127$ & $0.011 \pm 0.084$ & 5.53 & 0.08 & 74.14 & 78.18 & 0.82 & 0.952 & 0.021 & 9918 \\
\hline $75 \mathrm{~km} \mathrm{~s}$ & $0.205 \pm 0.146$ & $0.194 \pm 0.125$ & $0.010 \pm 0.081$ & 5.28 & 0.08 & 74.81 & 78.82 & 0.83 & 0.971 & 0.016 & 8361 \\
\hline $75 \mathrm{~km} \mathrm{sr}$ & $0.203 \pm 0.145$ & $0.194 \pm 0.124$ & $0.008 \pm 0.079$ & 4.32 & 0.08 & 75.33 & 79.32 & 0.84 & 0.980 & 0.012 & 7674 \\
\hline $100 \mathrm{~km}$ & $0.209 \pm 0.144$ & $0.200 \pm 0.128$ & $0.009 \pm 0.083$ & 4.23 & 0.08 & 75.23 & 79.53 & 0.82 & 0.925 & 0.023 & 10143 \\
\hline $100 \mathrm{~km} \mathrm{~s}$ & $0.202 \pm 0.144$ & $0.195 \pm 0.126$ & $0.008 \pm 0.080$ & 3.94 & 0.08 & 76.06 & 80.21 & 0.83 & 0.948 & 0.018 & 8481 \\
\hline $100 \mathrm{~km} \mathrm{sr}$ & $0.201 \pm 0.142$ & $0.195 \pm 0.125$ & $0.007 \pm 0.078$ & 3.35 & 0.08 & 76.55 & 80.74 & 0.84 & 0.949 & 0.016 & 8183 \\
\hline $25 \mathrm{~km}$ & $0.247 \pm 0.173$ & $0.197 \pm 0.121$ & $0.050 \pm 0.109$ & 25.18 & 0.12 & 57.14 & 61.87 & 0.78 & 1.113 & 0.027 & 6283 \\
\hline $25 \mathrm{~km} \mathrm{~s}$ & $0.242 \pm 0.166$ & $0.194 \pm 0.117$ & $0.049 \pm 0.107$ & 25.13 & 0.12 & 57.23 & 61.91 & 0.77 & 1.093 & 0.031 & 5639 \\
\hline $50 \mathrm{~km}$ & $0.228 \pm 0.157$ & $0.196 \pm 0.124$ & $0.032 \pm 0.093$ & 16.47 & 0.10 & 67.02 & 70.87 & 0.81 & 1.021 & 0.028 & 8768 \\
\hline $50 \mathrm{~km} \mathrm{~s}$ & $0.223 \pm 0.152$ & $0.192 \pm 0.121$ & $0.032 \pm 0.090$ & 16.47 & 0.10 & 67.27 & 71.04 & 0.81 & 1.016 & 0.029 & 7569 \\
\hline $50 \mathrm{~km} \mathrm{sr}$ & $0.224 \pm 0.155$ & $0.194 \pm 0.125$ & $0.030 \pm 0.088$ & 15.34 & 0.09 & 66.76 & 70.45 & 0.82 & 1.018 & 0.026 & 5557 \\
\hline $75 \mathrm{~km}$ & $0.219 \pm 0.146$ & $0.195 \pm 0.125$ & $0.024 \pm 0.084$ & 12.17 & 0.09 & 72.28 & 76.27 & 0.82 & 0.962 & 0.031 & 9469 \\
\hline $75 \mathrm{~km} \mathrm{~s}$ & $0.214 \pm 0.142$ & $0.191 \pm 0.121$ & $0.023 \pm 0.081$ & 12.14 & 0.08 & 72.81 & 76.68 & 0.82 & 0.964 & 0.030 & 8030 \\
\hline $75 \mathrm{~km} \mathrm{sr}$ & $0.213 \pm 0.142$ & $0.191 \pm 0.121$ & $0.022 \pm 0.079$ & 11.51 & 0.08 & 73.41 & 77.30 & 0.83 & 0.972 & 0.027 & 7352 \\
\hline $100 \mathrm{~km}$ & $0.215 \pm 0.142$ & $0.195 \pm 0.125$ & $0.020 \pm 0.082$ & 10.00 & 0.08 & 74.40 & 77.95 & 0.82 & 0.929 & 0.033 & 9669 \\
\hline $100 \mathrm{~km} \mathrm{~s}$ & $0.210 \pm 0.138$ & $0.191 \pm 0.121$ & $0.019 \pm 0.079$ & 10.09 & 0.08 & 74.92 & 78.32 & 0.82 & 0.937 & 0.031 & 8147 \\
\hline $100 \mathrm{~km} \mathrm{sr}$ & $0.209 \pm 0.138$ & $0.191 \pm 0.121$ & $0.018 \pm 0.077$ & 9.37 & 0.08 & 75.67 & 79.06 & 0.83 & 0.942 & 0.029 & 7847 \\
\hline
\end{tabular}


4. Aerosol spatial variability and hot spots

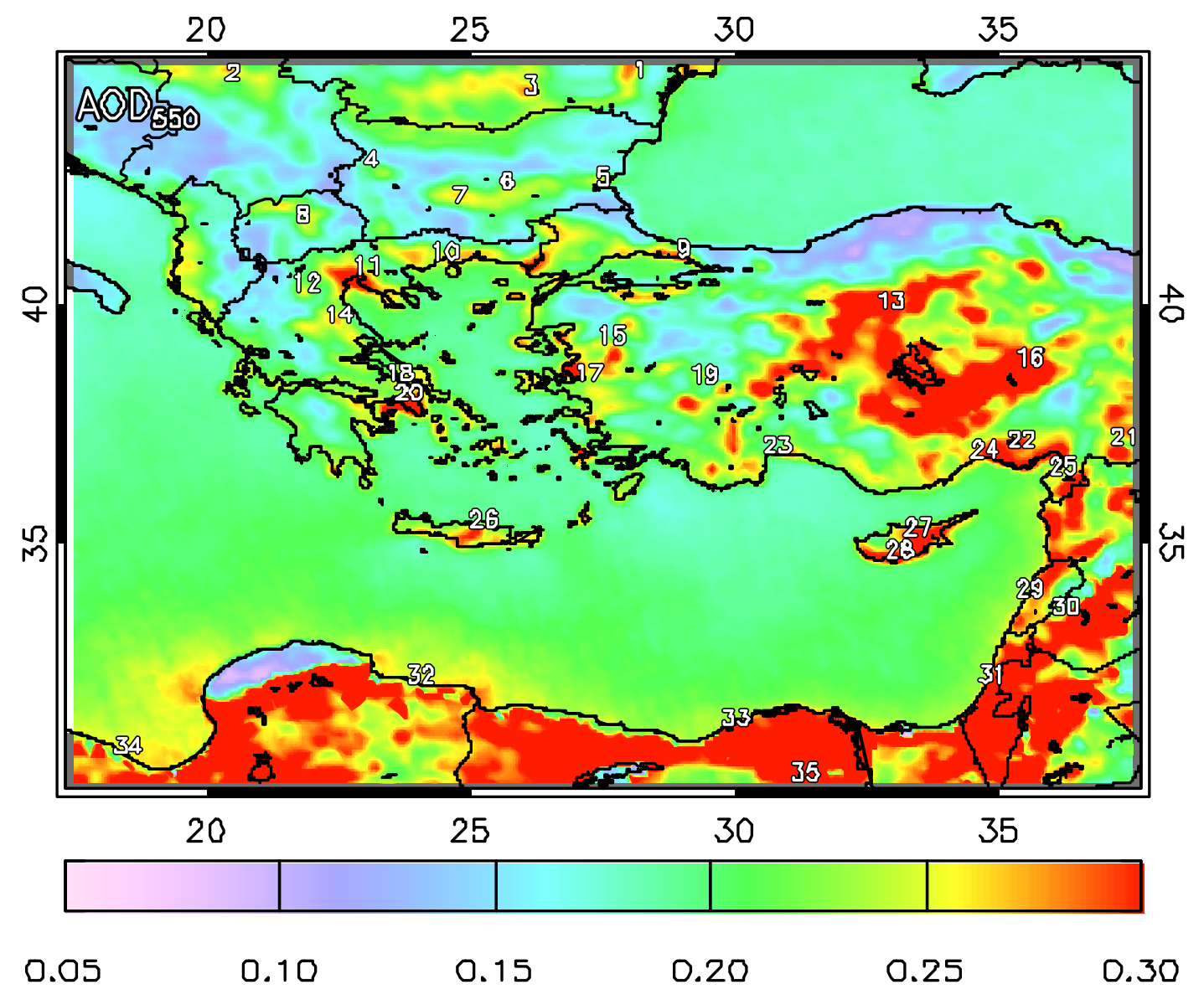

Figure S10. $A_{50}$ patterns over the Eastern Mediterranean as seen by MODIS Aqua during the period 7/2002-12/2012. 
a)

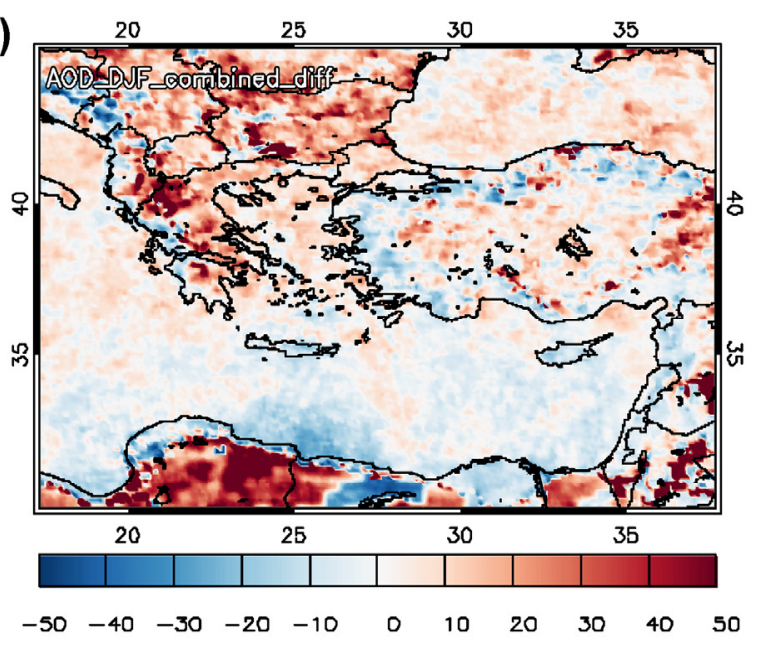

c)

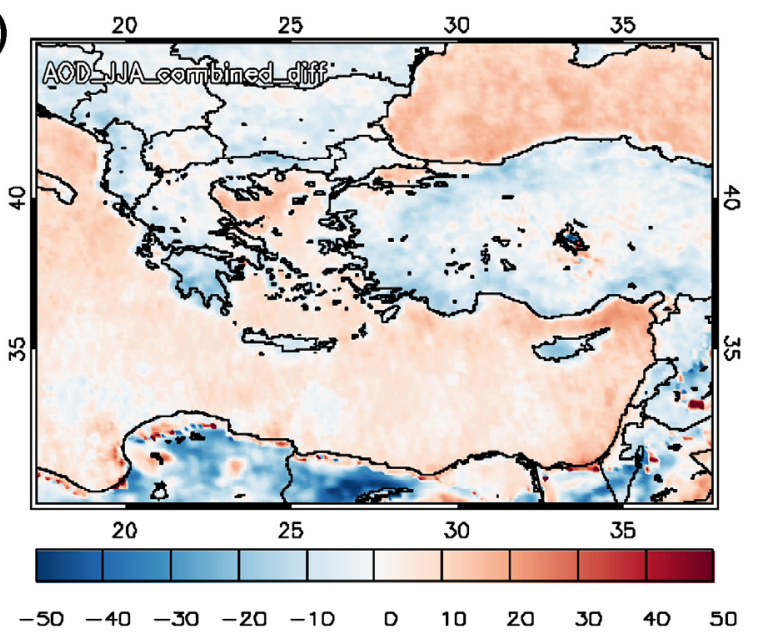

b)

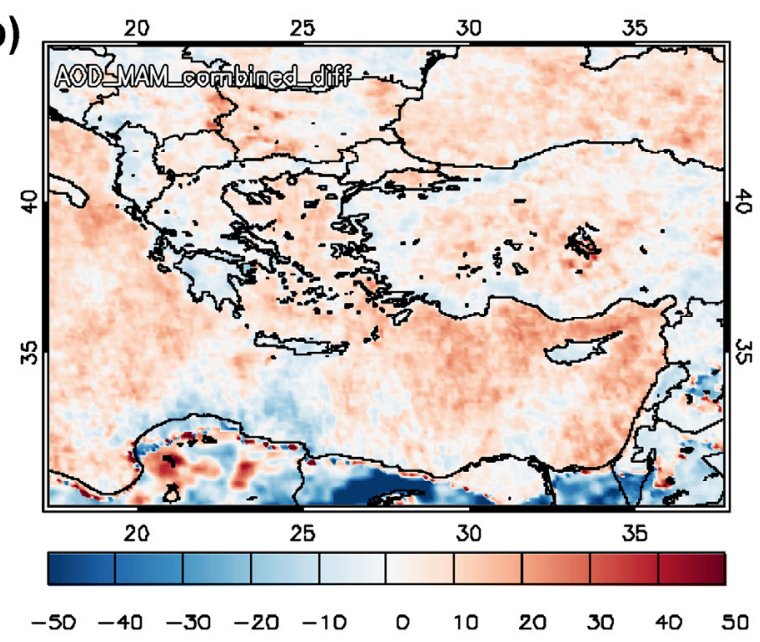

d)

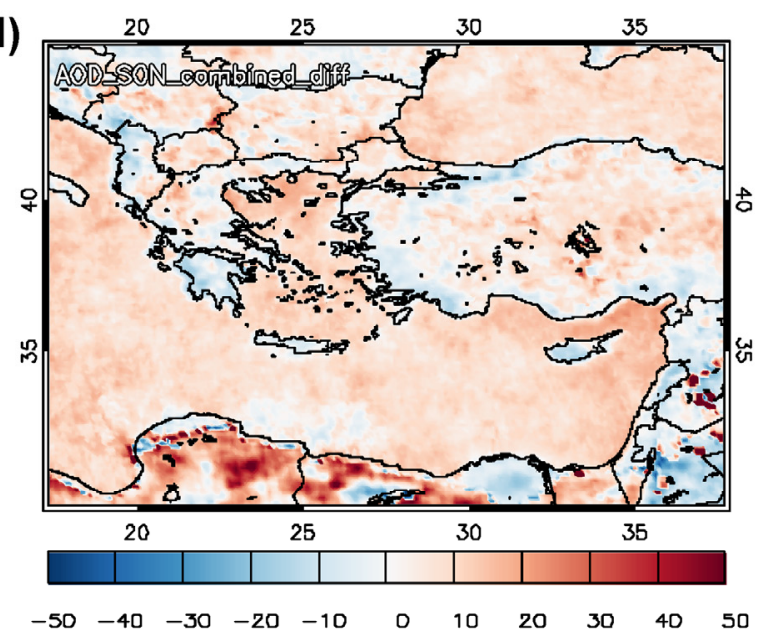

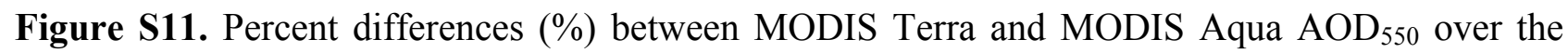
Eastern Mediterranean for: a) Winter, b) Spring, c) Summer, d) Autumn. 
a)

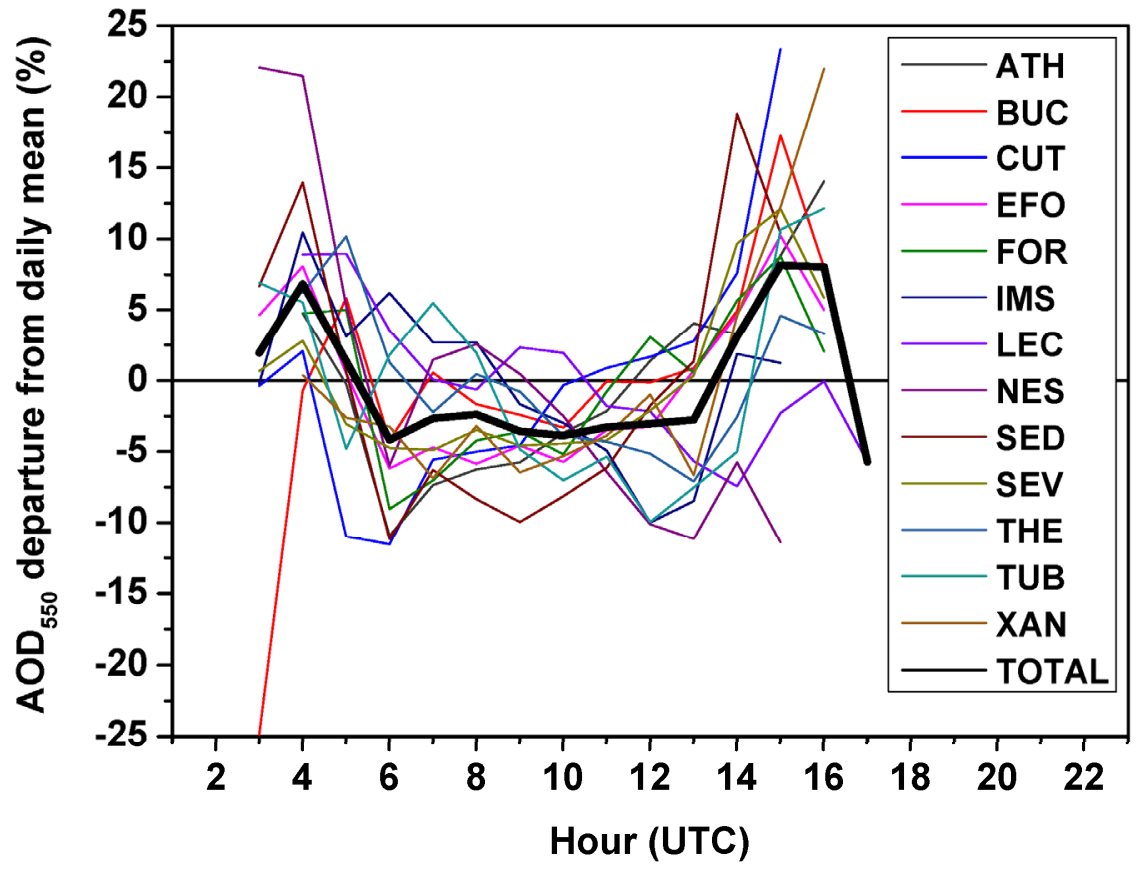

b)

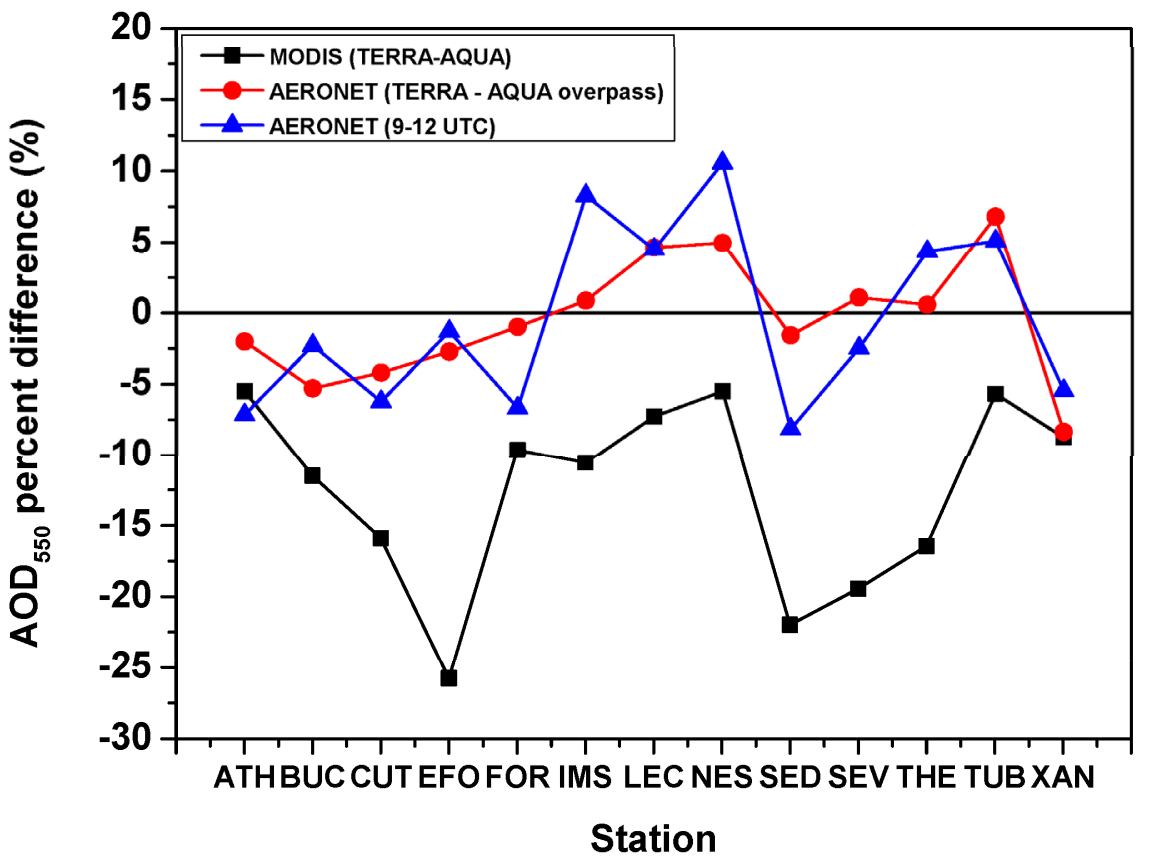

Figure S12. (a) Diurnal variability of $\mathrm{AOD}_{550}$ (quadratically interpolated) based on sunphotometric measurements at the 13 Eastern Mediterranean AERONET stations used in this work. (b) Difference between MODIS Terra and MODIS Aqua $\mathrm{AOD}_{550}$ retrievals (black color), difference

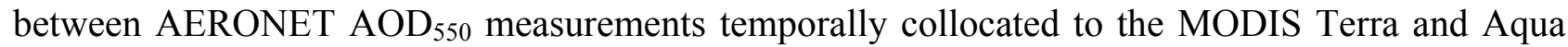
data (red color) and difference between AERONET AOD S50 $_{50}$ measurements at 9 (close to the average MODIS Terra overpass time) and 12 UTC (close to the average MODIS Aqua overpass time) for each station (blue color). 


\section{Contribution of different aerosol types to the total $\mathrm{AOD}_{\mathbf{5 5 0}}$}

a)

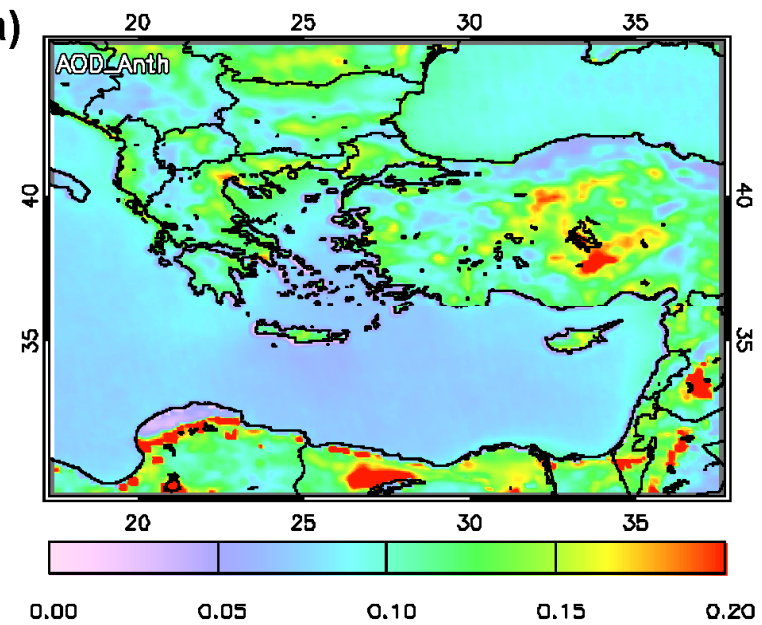

c)

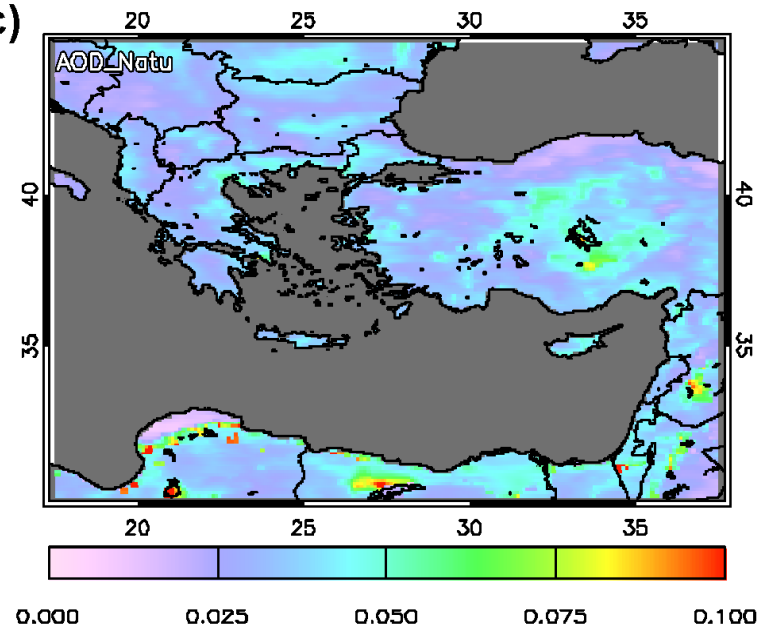

b)

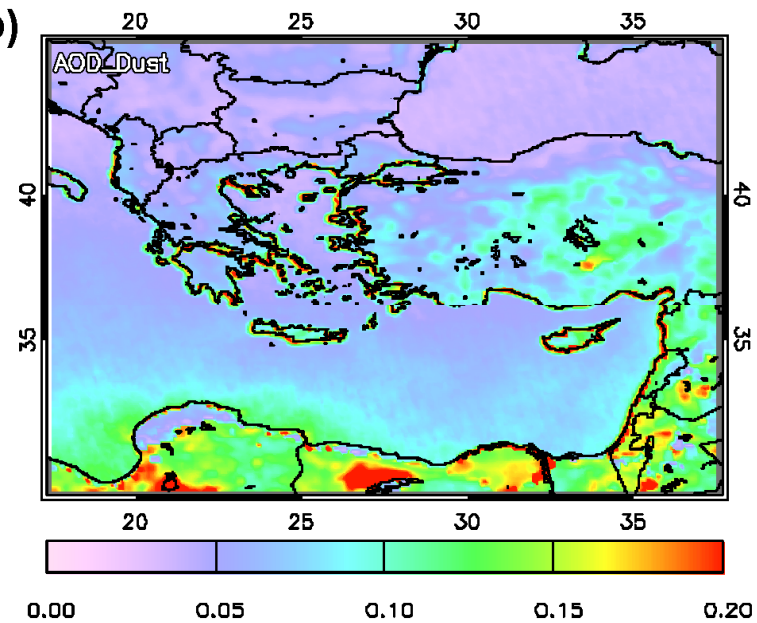

d)

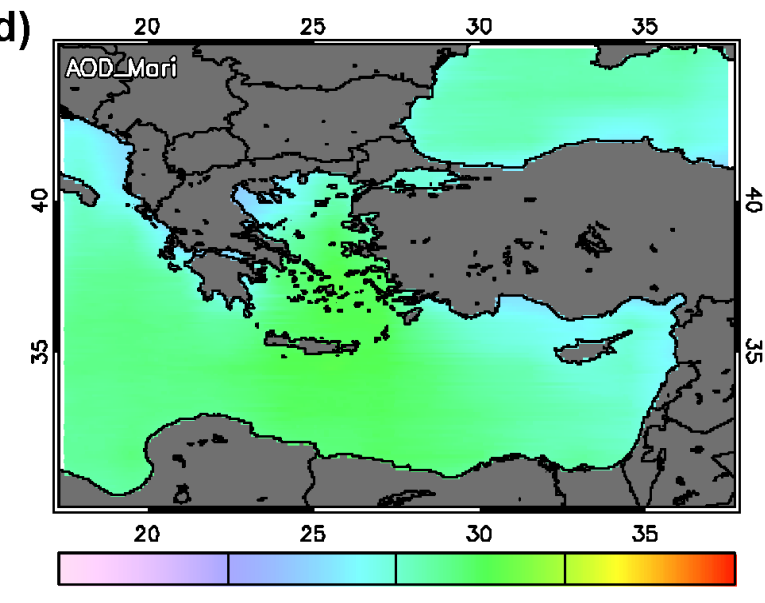

Figure S13. (a) Anthropogenic aerosol $\left(\tau_{\mathrm{a}}\right),(\mathrm{b})$ dust $\left(\tau_{\mathrm{d}}\right)$, (c) fine mode natural aerosol $\left(\tau_{\mathrm{n}}\right)$ and $(\mathrm{d})$ marine aerosol $\left(\tau_{\mathrm{m}}\right)$ patterns over the Eastern Mediterranean based on MODIS Aqua observations during the period 7/2002-12/2012. 

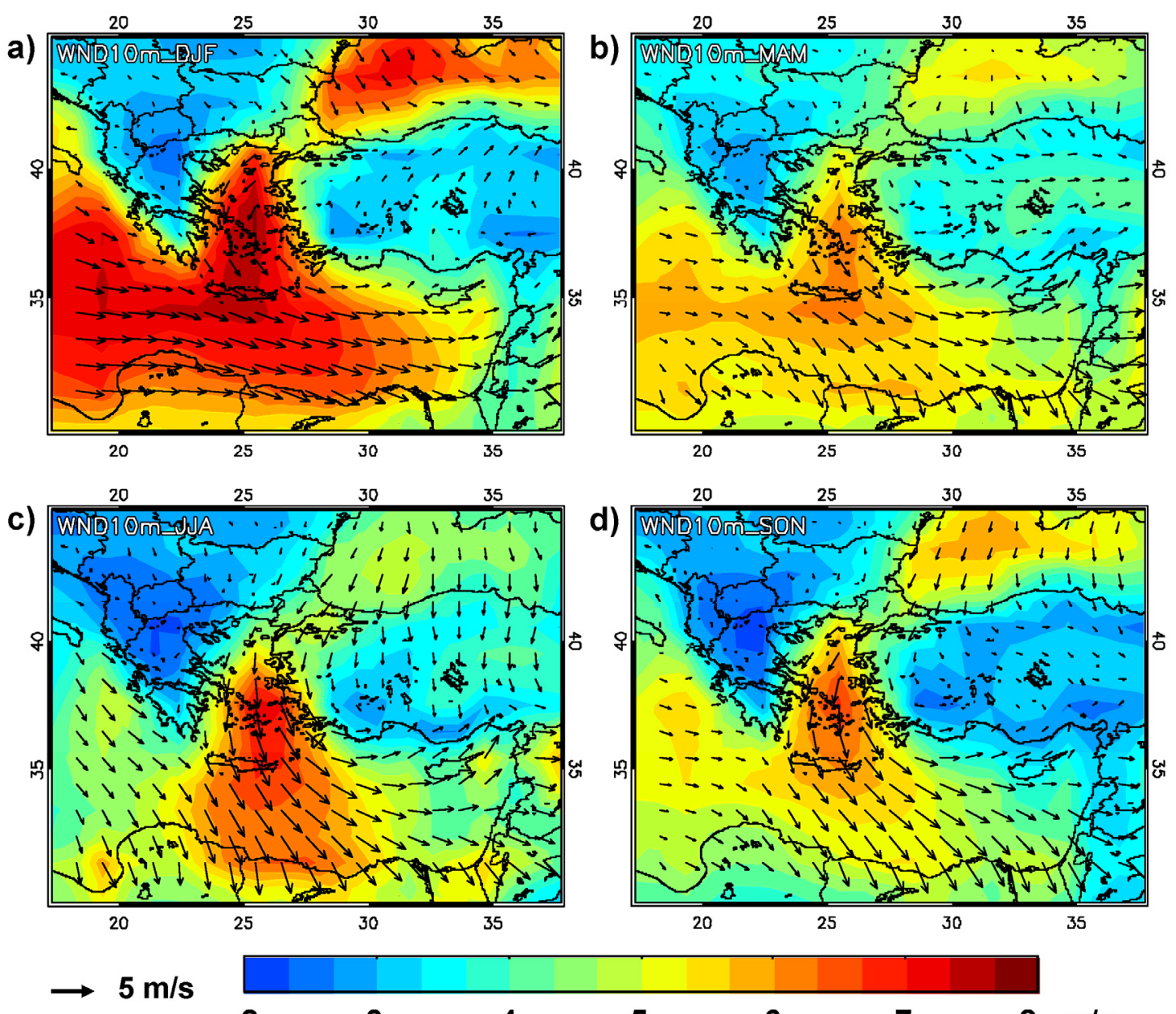

\section{5}

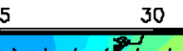

30

35 $12+1+1+1+1+1$ $=0 x=0+1+1+1$
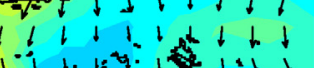

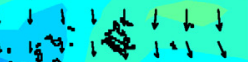

$+1$

$\checkmark$

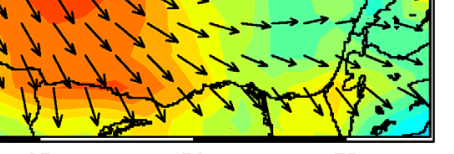

$2530 \quad 35$ d)

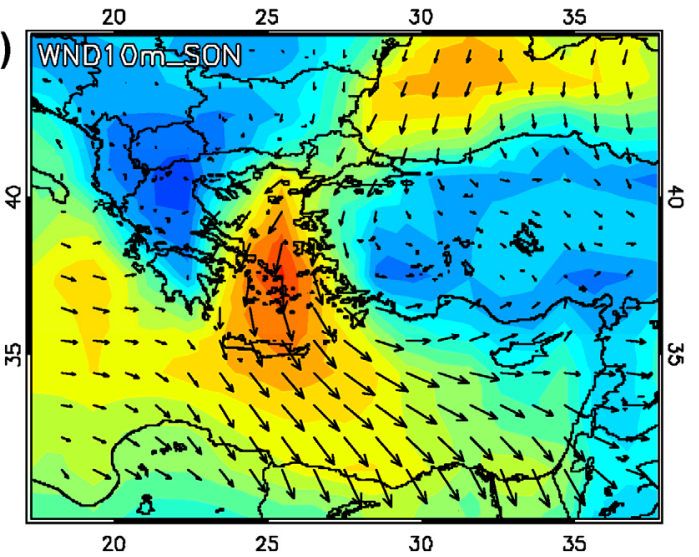

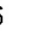

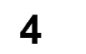

5

6

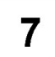

$8 \mathrm{~m} / \mathrm{s}$

Figure S14. Average near surface wind speed patterns (colorscale) and wind vectors over the Eastern Mediterranean for: a) Winter, b) Spring, c) Summer and d) Autumn. For the production of the maps wind field data at $10 \mathrm{~m}$ above surface from the ERA-Interim reanalysis are used. The wind data are for 12:00 UTC (close to MODIS Aqua overpass time) covering the period 2000-2012. 
6. Seasonal contribution of different aerosol types to the total $\mathrm{AOD}_{550}$
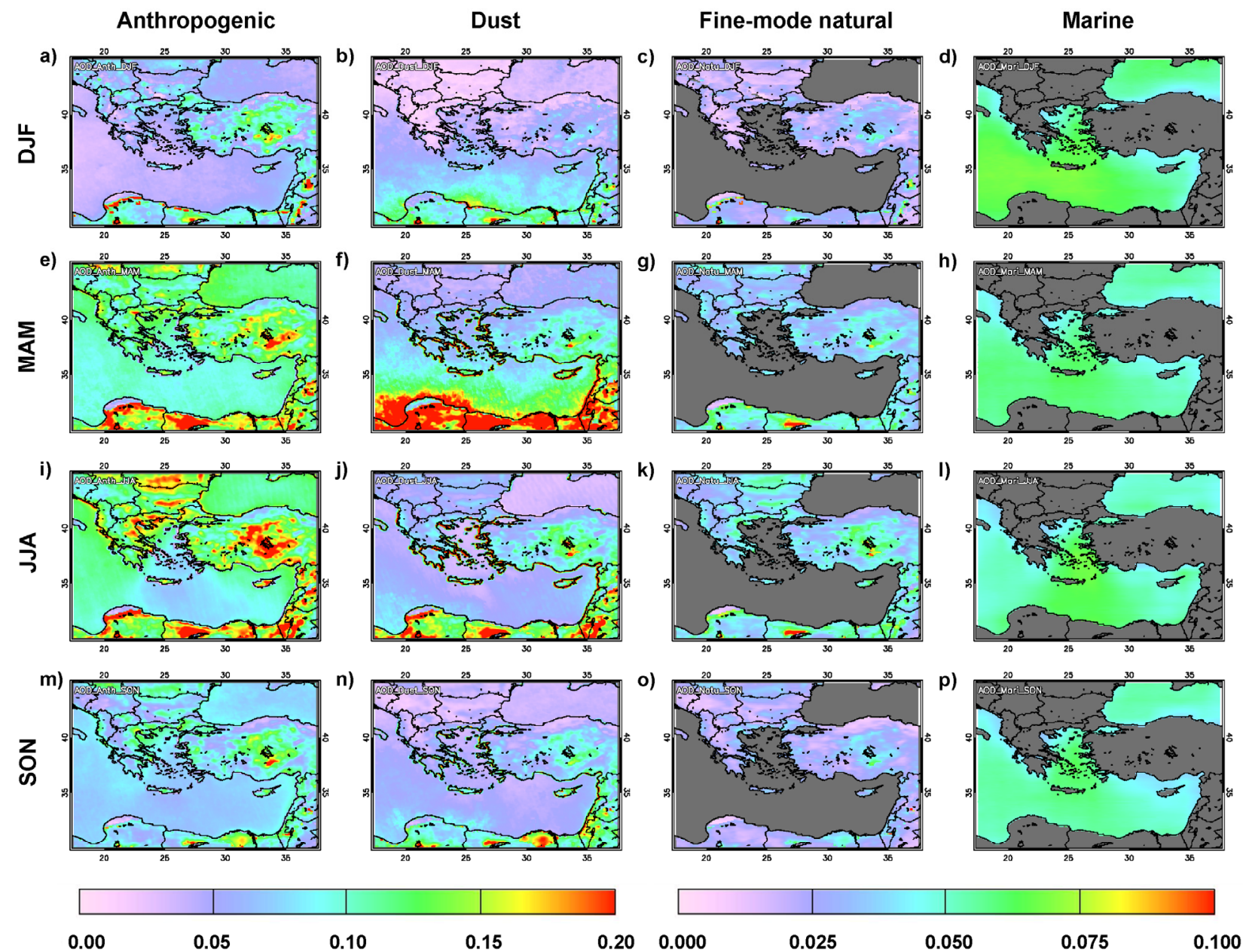

Figure S15. Seasonal (a, e, i, m) anthropogenic aerosol $\left(\tau_{\mathrm{a}}\right),(\mathrm{b}, \mathrm{f}, \mathrm{j}, \mathrm{n})$ dust $\left(\tau_{\mathrm{d}}\right),(\mathrm{c}, \mathrm{g}, \mathrm{k}, \mathrm{o})$ fine mode natural aerosol $\left(\tau_{\mathrm{n}}\right)$ and $(\mathrm{d}, \mathrm{h}, \mathrm{i}, \mathrm{p})$ marine aerosol $\left(\tau_{\mathrm{m}}\right)$ patterns over the Eastern Mediterranean based on MODIS Terra observations during the period 3/2000-12/2012 (3/2000-12/2007 for regions of North Africa covered by DB data only). 

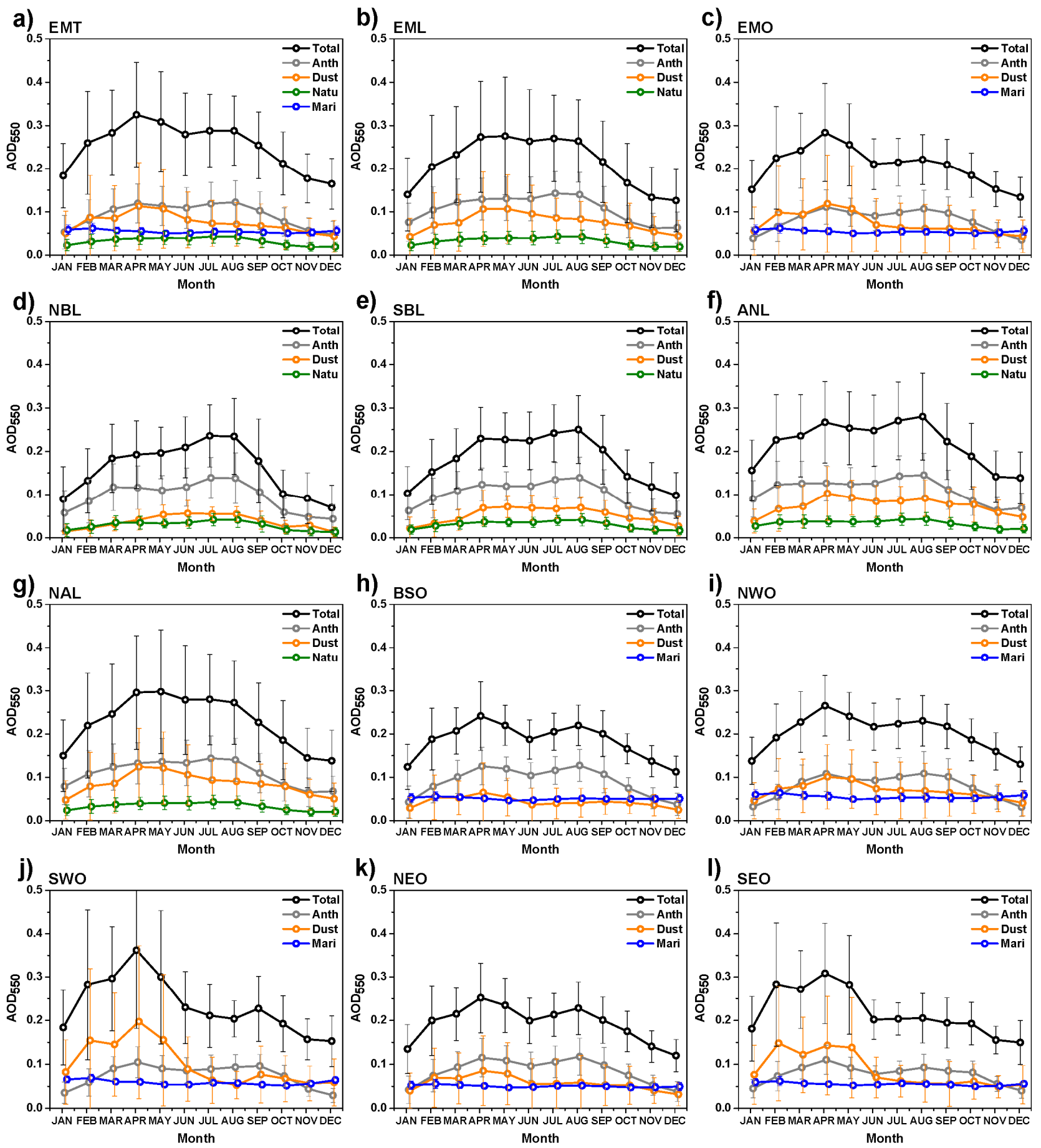

Figure S16. Seasonal variability of anthropogenic aerosols $\left(\tau_{\mathrm{a}}\right)$, dust $\left(\tau_{\mathrm{d}}\right)$, fine mode natural aerosols $\left(\tau_{\mathrm{n}}\right)$ and marine aerosols $\left(\tau_{\mathrm{m}}\right)$ over the Eastern Mediterranean (EMT), over the land covered part (EML), over the oceanic part (EMO) and over the 9 sub-regions of the Eastern Mediterranean appearing in Fig. 1 based on MODIS Aqua observations. The error bars represent the $\pm 1 \sigma$ values calculated from monthly gridded data. 


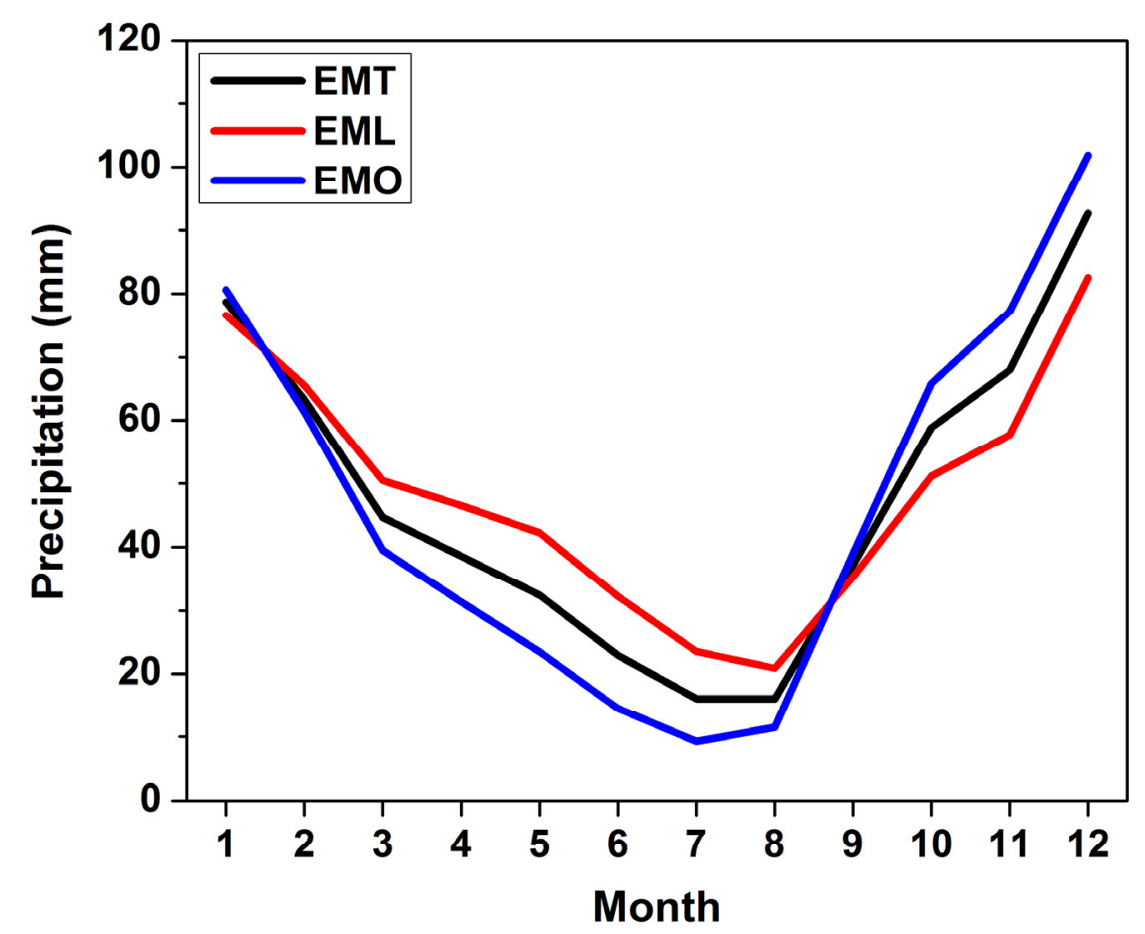

Figure S17. Seasonal variability of precipitation (in $\mathrm{mm}$ ) over the Eastern Mediterranean (black color), over the land covered part (red color) and over the oceanic part (blue color) from 3B43 TRMM and Other Sources Monthly Rainfall Product (2000-2012). 